\title{
Vitamin D, Autoimmune Disease and Rheumatoid Arthritis
}

\author{
Stephanie R. Harrison ${ }^{1,2}$ • Danyang $\mathrm{Li}^{1}$ • Louisa E. Jeffery ${ }^{3} \cdot$ Karim Raza $^{2,4} \cdot$ Martin Hewison $^{1,5}[$
}

Received: 12 December 2018 / Accepted: 18 June 2019 / Published online: 8 July 2019

(c) The Author(s) 2019

\begin{abstract}
Vitamin D has been reported to influence physiological systems that extend far beyond its established functions in calcium and bone homeostasis. Prominent amongst these are the potent immunomodulatory effects of the active form of vitamin D, 1,25-dihydroxyvitamin $\mathrm{D} 3\left(1,25-(\mathrm{OH})_{2} \mathrm{D} 3\right)$. The nuclear vitamin $\mathrm{D}$ receptor (VDR) for $1,25-(\mathrm{OH})_{2} \mathrm{D} 3$ is expressed by many cells within the immune system and resulting effects include modulation of T cell phenotype to suppress pro-inflammatory Th1 and Th17 CD4+ T cells and promote tolerogenic regulatory T cells. In addition, antigen-presenting cells have been shown to express the enzyme $1 \alpha$-hydroxylase that converts precursor 25 -hydroxyvitamin D3 (25-OHD3) to 1,25-(OH) 2 D3, so that immune microenvironments are able to both activate and respond to vitamin D. As a consequence of this local, intracrine, system, immune responses may vary according to the availability of 25-OHD3, and vitamin D deficiency has been linked to various autoimmune disorders including rheumatoid arthritis (RA). The aim of this review is to explore the immune activities of vitamin D that impact autoimmune disease, with specific reference to RA. As well as outlining the mechanisms linking vitamin D with autoimmune disease, the review will also describe the different studies that have linked vitamin D status to RA, and the current supplementation studies that have explored the potential benefits of vitamin D for prevention or treatment of RA. The overall aim of the review is to provide a fresh perspective on the potential role of vitamin $\mathrm{D}$ in RA pathogenesis and treatment.
\end{abstract}

Keywords Vitamin D $\cdot$ Vitamin D receptor $\cdot$ Autoimmune disease $\cdot$ Rheumatoid arthritis $\cdot$ Inflammation $\cdot \mathrm{T}$ cell

Electronic supplementary material The online version of this article (https://doi.org/10.1007/s00223-019-00577-2) contains supplementary material, which is available to authorized users.

Martin Hewison

m.hewison@bham.ac.uk

1 Institute of Metabolism and Systems Research, The University of Birmingham, Birmingham B15 2TT, UK

2 Department of Rheumatology, Sandwell and West, Birmingham Hospitals NHS Trust, Birmingham B18 7QH, UK

3 Institute of Translation Medicine, The University of Birmingham, Birmingham B15 2TT, UK

4 Institute of Inflammation and Ageing, Arthritis Research UK Rheumatoid Arthritis Pathogenesis Centre of Excellence and MRC Arthritis Research UK Centre for Musculoskeletal Ageing Research, University of Birmingham, Birmingham B15 2TT, UK

5 Centre for Endocrinology, Diabetes and Metabolism, Birmingham Health Partners, Birmingham B15 2TT, UK

\section{Introduction}

Vitamin D is a secosteroid which can be obtained from the diet (in particular from oily fish, eggs, dairy products and fortified foods). However, in humans, the majority of vitamin $\mathrm{D}$ is synthesised in the skin from the precursor molecule 7-dehydrocholesterol, which undergoes a series of UV lightmediated modifications to generate parental vitamin D3 [1]. Vitamin D was first recognised for its role in bone mineralisation and calcium regulation, with vitamin D deficiency associated with the bone disease rickets [2]. More recently, vitamin $\mathrm{D}$ has been reported to exert many extra-skeletal effects [3] with association studies linking vitamin D status to a broad range of human health issues. Prominent amongst these is the proposed role of vitamin D in the pathophysiology of autoimmune disease, including insulin-dependent type 1 diabetes mellitus (T1D) [4], autoimmune thyroid disease [5, 6], multiple sclerosis (MS), inflammatory bowel disease (IBD) [7], systemic lupus erythematosus (SLE) [8] and rheumatoid arthritis (RA) [9]. The underlying mechanisms by which vitamin $\mathrm{D}$ impacts autoimmune disease remain 
elusive, and it is still not clear whether vitamin D deficiency contributes to autoimmune disease pathogenesis or whether it is marker of disease progression and severity. In this article, we address these issues with specific reference to the role of vitamin D in RA. We discuss the potential clinical significance, and the mechanisms of action of vitamin $\mathrm{D}$ in RA, and suggest areas where future research is needed.

\section{Vitamin D in Health}

Humans obtain vitamin D in two forms; vitamin D2 (ergocalciferol, derived from plant ergosterols) and vitamin D3 (cholecalciferol), which differ in the number/location of double carbon-carbon bonds. Vitamin D2 has only two $\mathrm{C}=\mathrm{C}$ bonds, whilst vitamin D3 has three, affording D2 a lower affinity for vitamin D-binding protein (DBP), increasing clearance and reduced bioavailability; thus, vitamin D3 is the main form of vitamin D used by humans. Generation of active, hormonal, vitamin D3 involves a series of non-enzymatic and enzymatic processes. Firstly, 7-dehydrocholesterol is converted to vitamin D3 when exposed to UVB light in the dermis. Vitamin D3 is then converted to 25-hydroxycholecalciferol (25-OHD3) by the enzyme 25-hydroxylase (CYP2R1) located predominantly in the liver [10]. The final step in generating active 1,25-dihydroxycholecalciferol $\left(1,25-(\mathrm{OH})_{2} \mathrm{D} 3\right)$ is mediated by the enzyme 25 -hydroxyvitamin D-1 $\alpha$-hydroxylase (CYP27B1), which is abundant in the proximal tubule cells of the kidney [11]. This step is responsible for the majority of circulating $1,25-(\mathrm{OH})_{2} \mathrm{D} 3$, but CYP27B1 is also expressed by a variety of non-renal tissues [12], including several immune cell subsets [13-15], suggesting that these cells also have significant capacity to generate $1,25-(\mathrm{OH})_{2} \mathrm{D} 3$, with this process being instrumental in various autocrine and paracrine cell responses to vitamin D [16, 17]. Moreover, whilst renal CYP27B1 is tightly regulated by parathyroid hormone, fibroblast growth factor 23 and 1,25- $(\mathrm{OH})_{2} \mathrm{D} 3$ itself, extra-renal CYP27B 1 does not appear to be subject to the same regulatory constraints [18, 19]. Instead extra-renal synthesis of $1,25-(\mathrm{OH})_{2} \mathrm{D} 3$ appears to be more dependent on the availability of 25-OHD3. In view of the fact that 25-OHD3 is the main determinant of serum vitamin D status, it is highly likely that extrarenal synthesis of $1,25-(\mathrm{OH})_{2} \mathrm{D} 3$ will therefore be strongly influenced by vitamin D deficiency/sufficiency. The availability of 25-OHD3 is also affected by circulating serum carrier proteins for vitamin D: Vitamin D-Binding Protein (VBP), and to a lesser extent albumin [20,21]. Levels of $1,25-(\mathrm{OH})_{2} \mathrm{D} 3$ in either renal or extra-renal settings are also influenced by catabolism of $1,25-(\mathrm{OH})_{2} \mathrm{D} 3$ to inactive metabolites which is primarily controlled by the enzyme 24-hydroxylase (CYP24A1) [22], with mutations in the
CYP24A1 gene being associated with dysregulated catabolism of $1,25-(\mathrm{OH})_{2} \mathrm{D} 3$ [23].

Active $1,25-(\mathrm{OH})_{2} \mathrm{D} 3$ has an established role in regulating bone metabolism and calcium homeostasis, but it has also been shown to modulate key mechanisms in innate and adaptive immunity [24-26] (Fig. 1). The nuclear receptor for $1,25-(\mathrm{OH})_{2} \mathrm{D} 3$ (the vitamin $\mathrm{D}$ receptor (VDR)) is expressed by a plethora of immune cells, including monocytes/macrophage, dendritic cells (DC), neutrophils and B and T cells $[27,28]$. This, coupled with the capacity for localised CYP27B1-mediated synthesis of $1,25-(\mathrm{OH})_{2} \mathrm{D} 3$ by monocytes, macrophages and DC [13,14], supports a role for vitamin $\mathrm{D}$ as an important contributor to normal immune function. The remainder of the review will focus on this activity of vitamin $\mathrm{D}$ and the impact that this may have on the chronic inflammatory/autoimmune disease RA.

\section{Vitamin D and Immunity}

The multi-modal innate immune system is the body's first line of defence against pathogens, comprising physical barriers (e.g. epithelium), chemical barriers (e.g. stomach acid), complement proteins and cellular responses such as those mediated by macrophage, DC and neutrophils. Vitamin $\mathrm{D}$ participates in several of these processes, including the maintenance of barrier function in the intestine, by regulating tight junctions [29] and intestinal epithelial cell apoptosis [30]. However, to date, studies of vitamin D and innate immunity have predominantly explored its impact on antigen-presenting cells, such as macrophages and DC, which participate in the recognition of and response to pathogenassociated molecular patterns (PAMPs) via pattern recognition receptors (PRR) [25, 26] (see Fig. 1). DNA target sequences for 1,25-(OH) $)_{2} \mathrm{D} 3$-bound to VDR, referred to as vitamin D response elements (VDRE) have been found in multiple genes associated with PRR responses, including the antibacterial proteins NOD2 [31], hepcidin antimicrobial protein (HAMP) [32], cathelicidin (CAMP) [33], B-defensin 2 (DEFB4) [33, 34] and TREM-1 [35]. Toll-Like Receptors (TLRs) are an important group of PRR, and 1,25-(OH $)_{2} \mathrm{D} 3$ has been shown to downregulate TLR2 and TLR4 in monocytes [36], abrogating over-elaboration of TLR immune responses to PAMPs and damage-associated molecular patterns (DAMPs). In a separate study, methylation of the Vitamin D Receptor (VDR) gene and single-nucleotide polymorphisms in the VDR were also found to alter VDR-mediated TLR1/2 signalling in monocytes [37].

Vitamin D is also known to differentially regulate innate immune cell subsets, influencing cell maturation, metabolism and antigen presentation, alongside response to and production of cytokines and chemokines [13, 14, 38, 39]. Notably, mature DC express CYP27B1 but little VDR, 


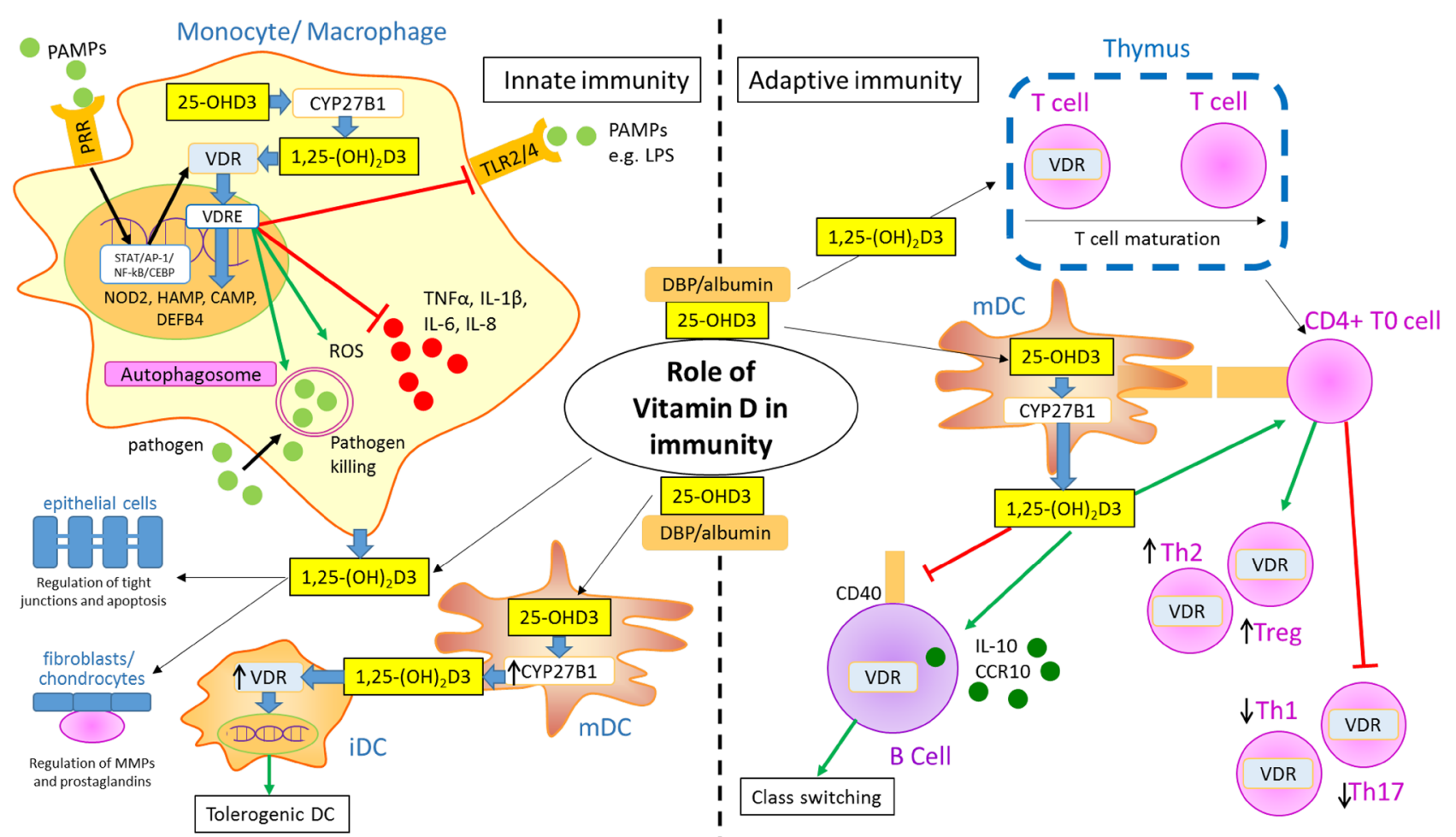

Fig. 1 Role of vitamin D in the immune system. Schematic representation of cells from the innate and adaptive immune systems. Monocyte/macrophages from the innate immune system expression pattern recognition receptors (PRR) such as toll-like receptors (TLR), and response to pathogen-associated molecular patterns (PAMPs) such as lipopolysaccharide (LPS). PAMP-PRR responses include induction of transcription to increased expression of the vitamin D receptor (VDR) and the vitamin D-activating enzyme $1 \alpha$-hydroxylase (CYP27B1) via STAT 1 or $5, \mathrm{AP}-1, \mathrm{NF}-\mathrm{\kappa B}$ or CEBP response elements. This increases monocyte/macrophage capacity to metabolise 25-hydroxyvitamin D3 (25-OHD3) to 1,25-dihydroxyvitamin D3 $\left(1,25-(\mathrm{OH})_{2} \mathrm{D} 3\right)$, which then interacts with VDR to regulate gene expression via DNA vitamin D response elements (VDRE). Prominent target genes for regulation by $1,25-(\mathrm{OH})_{2} \mathrm{D} 3$ include Nucleotide-binding oligomerization domain-containing protein 2 (NOD2), hepcidin antimicrobial protein (HAMP), cathelicidin (CAMP) and $\beta$-defensin 2 (DEFB4). 1,25-(OH) $)_{2} \mathrm{D} 3$ also enhances pathogen kill-

whereas the converse is true for immature DC [13]. This has led to the hypothesis that mature DC may in fact produce vitamin D locally on activation, which then acts on immature DC to modulate immune responses $[13,40]$. The principal effect of $1,25-(\mathrm{OH})_{2} \mathrm{D} 3$ on $\mathrm{DC}$ is to suppress maturation markers such as CD80/CD86 [41-43] and CD83 [44], increase IL-10 production and decrease pro-inflammatory cytokines $[41,45,46]$. In this way, $1,25(\mathrm{OH})_{2} \mathrm{D} 3$ promotes an immature, tolerogenic DC phenotype [47-49], thereby reducing antigen presentation to $\mathrm{T}$ cells.

Adaptive immune cells are also modulated directly by $1,25-(\mathrm{OH})_{2} \mathrm{D} 3$, with VDR being transiently expressed by developing thymocytes, and re-activation of VDR expression in peripheral $\mathrm{T}$ and $\mathrm{B}$ cells following immune challenge ing by inducing autophagy and reactive oxygen species (ROS), but acts to inhibit inflammation by suppressing inflammatory cytokines and expression of TLR2/4. Monocytes/macrophages may contribute to local levels of $1,25-(\mathrm{OH})_{2} \mathrm{D} 3$ which may then act on non-immune cells such as local tissue fibroblasts, chondrocytes or epithelial cells. For other innate immunity cells such as dendritic cells (DC), differentiation of these cells from immature (iDC) to mature (mDC) phenotypes is associated with increased expression of CYP27B1 but decreased expression of VDR, suggesting local conversion of $25-\mathrm{OHD} 3$ to $1,25-(\mathrm{OH}) 2 \mathrm{D} 3$, which results in a paracrine effect to generate tolerogenic DC. Synthesis of $1,25-(\mathrm{OH})_{2} \mathrm{D} 3$ by $\mathrm{mDC}$ may also have paracrine effects on cells from the adaptive immune system such as T cells which, when activated, express VDR and respond to 1,25- $(\mathrm{OH})_{2} \mathrm{D} 3$ by inducing Th2 and Treg phenotypes whilst suppressing Th1 and Th17 inflammatory phenotypes. 1,25- $(\mathrm{OH})_{2} \mathrm{D} 3$ can also act on B cells to decrease CD40 expression and enhance class switching

$[50,51] .1,25-(\mathrm{OH})_{2} \mathrm{D} 3$ was initially thought to act primarily as a regulator of $\mathrm{T}$ and $\mathrm{B}$ cell proliferation, but is now known to play a more important role in regulating $\mathrm{T}$ cell phenotype [24, 52-54]. In particular, 1,25-(OH $)_{2} \mathrm{D} 3$ has been shown to suppress inflammatory interleukin-17 expressing CD4+ T-helper (Th) cells (Th17) [55] and Th1 cells [56], whilst promoting differentiation of Th2 cells [57] and regulatory T cells (Treg) [58, 59] (see Fig. 1). However, vitamin $\mathrm{D}$ may also promote some immune responses by enhancing effector $\mathrm{T}$ cell responses including CD8+ cytotoxic function [53], and other studies have reported a role for $1,25-(\mathrm{OH})_{2} \mathrm{D} 3$ in promoting $\mathrm{T}$ cell receptor (TCR) expression and $\mathrm{T}$ cell activation [60]. Although less well studied, $1,25-(\mathrm{OH})_{2} \mathrm{D} 3$ has also been shown to modulate the function 
of other cytotoxic lymphocytes such as natural killer cells (NK), with apparent effects of NK cell activation [61]. Likewise, effects of vitamin D have been described for natural killer T cells (NKT), and NKT cell development is lost in mice lacking the $V D R$ gene [62]. In contrast to the wide range of data on vitamin $\mathrm{D}$ and $\mathrm{T}$ cells, there is a scarcity of detailed studies for effects of $1,25-(\mathrm{OH})_{2} \mathrm{D} 3$ on B cells, which may include indirect effects via $\mathrm{T}$ cell modulation [63], and direct B cell effects on class switching [64], IL-10 production [65] and CCR10 production [66].

\section{Vitamin D in Autoimmune Disease}

Given the proposed role for vitamin D as an immune regulator, it is perhaps unsurprising that vitamin $\mathrm{D}$ deficiency has been linked to both allergic [67] and autoimmune diseases [4-8, 68, 69]. The increasing incidence/prevalence of MS proportional to distance from the equator, suggests that environmental factors such as sunlight and vitamin D may be involved in disease aetiology [70]. This is further underlined by studies from the UK showing that risk of immune-related diseases is significantly influenced by the season of birth as the serum 25-OHD3 levels is associated with this [71]. Likewise, genetic variants associated with heritable effects on vitamin D status have also been linked to MS disease onset and progression [72, 73]. However, differences between genders [74], ethnic groups [75] and potentially different subtypes of MS [76], make it difficult to decipher the exact role of vitamin D in MS. Furthermore, although vitamin D supplementation has been successful in ameliorating MS symptoms in some studies [77-80], this has not been demonstrated consistently [81]. Larger randomised controlled trials (RCTs) are now needed to establish whether vitamin D supplementation can reduce risk, severity and/or progression of MS. Similar to MS, vitamin D deficiency is also prevalent in SLE [82], where low serum vitamin D has been associated with dysregulation of autophagy [83], increased circulating levels of IFN $\alpha$ [84], increased CD4+/CD8+T cells and a reduction in pro-inflammatory cytokines [85]. Vitamin D intake has been shown to have variable impact on SLE, with some studies showing no effect on disease severity [86-88] whilst another study reported decreased disease activity in young adults with SLE [89]. As with MS, more research is needed to fully define optimal doses and timing of intervention for vitamin D supplementation.

T1D is another autoimmune disease with reported links to vitamin D status, with vitamin D deficiency correlating with T1D risk severity $[90,91]$. A prospective, non-blinded non-randomised controlled trial has also shown that T1D patients supplemented with vitamin D and with higher serum 25-OHD3 are more likely to have improved glycemic control [92]. T1D has also been linked to single-nucleotide polymorphic variants in the $C Y P 27 B 1$ [93-95] and $V D R$ [96, 97] genes. In vivo treatment with the active form of vitamin $\mathrm{D}, 1,25-(\mathrm{OH})_{2} \mathrm{D} 3$, was shown to completely suppress $\mathrm{T} 1 \mathrm{D}$ disease in the $N O D$ experimental mouse [98]. In humans, clinical trials involving supplementation with vitamin D3 or the precursor molecule $1 \alpha$-hydroxyvitamin D3 in T1D patients have produced mixed results; some studies have reported delay of $\beta$-cell destruction in supplemented trial groups compared to non-supplemented groups [99-101], whilst others found no significant improvements of on $\beta$-cell preservation $[102,103]$.

Vitamin D deficiency has also being linked to autoimmune gastrointestinal disorders such as Crohn's disease, a major form of IBD [104-107]. The role of vitamin D as a regulator of immune function in IBD has also been studied in vivo in mouse models. Knockout of the mouse genes for VDR $(V d r)$ [108] or 1 $\alpha$-hydroxylase (Cyp27b1) [109] shows increased severity of artificially induced colitis similar to IBD. Other studies have shown that vitamin D-deficient mice have increased severity of induced colitis, with this effect being linked to aberrant innate immune responses within the gastrointestinal tract [110]. Furthermore, it has been shown that the VDR, in conjunction with $1,25-(\mathrm{OH})_{2} \mathrm{D} 3$, protects against the onset of colitis in mice by maintaining barrier function within the gastrointestinal mucosal epithelium [111]. Despite these positive studies, it is still unclear whether vitamin D deficiency is a direct cause of IBD including Crohn's disease, or whether there is a reverse causation effect.

\section{Vitamin D and Rheumatoid Arthritis}

Rheumatoid arthritis (RA) is a chronic inflammatory/autoimmune arthritis characterised by synovitis of peripheral joints, with extra-articular manifestations. If untreated, unopposed inflammation leads to joint destruction, loss of function and disability, and RA is also associated with premature mortality secondary, at least in part, to the effects of chronic inflammation on cardiovascular health [112]. Like other autoimmune diseases, there is growing interest in the role of vitamin D deficiency in the aetiopathogenesis of RA [9]. RA is thought to be triggered by environmental factors [113], in patients with an underlying genetic susceptibility $[114,115]$ leading to dysfunction of innate and adaptive immunity, tipping the balance in preference of autoimmunity over tolerance [116]. Whilst smoking is well recognised as a strong environmental risk factor other potential factors include vitamin D [9]. 


\section{Vitamin D Status and RA Disease Risk and Progress}

In a recent meta-analysis and systematic review, Lin J et al. analysed 24 studies published prior to May 2015 whose focus was the relationship between serum 25-OHD3 and clinical/laboratory indices of RA disease activity. Overall, they reported an inverse relationship between serum 25-OHD3 and RA disease activity [117]. However, they also identified important differences between patient subgroups, including a stronger inverse relationship between RA disease activity and serum 25-OHD3 in studies from developing countries, and in low-latitude climates. Since the publication of this meta-analysis, further studies have been conducted. Therefore, to establish a clearer picture of whether vitamin D levels are indeed significantly lower in RA, and are linked to disease activity, all studies of vitamin D levels in RA patients currently listed on Pubmed are summarised in Table 1. The search terms "vitamin D levels" and "rheumatoid arthritis" were used, and no restrictions on study date were applied. In addition, studies included in the meta-analysis (referenced above) were also included. The collected studies listed in Table 1 underline the significant heterogeneity between studies and their findings, making it difficult to determine a clear role for vitamin D deficiency in the onset, progression and/ or severity of RA. Studies to date have been conducted in over 20 countries, which invariably means that there will be confounding differences in environmental factors including sunlight exposure and diet, and genetic factors. Moreover, the overwhelming majority of the reported studies were observational or cross-sectional by design, and as such can only report on the association between RA disease and vitamin $\mathrm{D}$, rather than a causal role.

RA is a heterogeneous disease, yet few studies have considered analysing RA subgroups based on antibody status, disease severity or duration. Where subgroups have been defined, this is often based on disease activity score 28 (DAS-28); a composite score that captures different subjective and objective measures of disease activity, hence the potential for skewing of results by one component. One study that did address this reported no correlation between vitamin D levels and DAS-28, with or without the inclusion of the patient global visual analogue scale score (Patient global VAS) - a scale for evaluating the patient's overall perception of their RA activity. However, patient global VAS on its own did correlate with serum vitamin D levels [118]. In 2015, Cooles et al. reported data showing the relationship between serum 25-OHD3 levels and various clinical parameters in early RA (median symptom duration 12 weeks, range 4-104 weeks) [119]. They found no clear association between 25-OHD3 and early RA, but in early osteoarthritis (OA) 25-OHD3 was inversely associated with global health visual analogue scale scores (GH-VAS). This suggests that $\mathrm{OA}$, which commonly co-exists with RA, may act as a confounder in interpreting the relationship between vitamin D and RA. These observations are intriguing, and need to be further explored to determine the role, if any, for vitamin $\mathrm{D}$ in pain and fatigue associated with $\mathrm{RA}$.

Relatively few studies have assessed the impact of RA treatment regimens on the apparent inverse correlation between serum 25-OHD3 and RA disease activity [120-122]. Treatment for RA is aimed at reducing disease activity, and therefore comparing serum 25-OHD3 levels with measures of disease activity after the initiation of treatment could mask prior effects of vitamin D deficiency on treatment naïve disease. Since the 1990s, an early and aggressive approach to the management of new RA has been widely used in order to maximise chances of inducing remission [123]. Today, this strategy is fully integrated in clinical practice, but its application in the context of low vitamin $\mathrm{D}$, and vitamin $\mathrm{D}$ replacement, for treatment naive, newly diagnosed RA patients, is still unclear.

As well as clinical and biochemical differences in subgroups of RA, there are also likely genetic differences which may influence the relative importance of vitamin D in the immunopathogenesis of disease. For example, Dennis et al. identified four distinct synovial tissue gene expression profiles in a cohort of RA patients [124]. Although some of these differences in gene expression may be related to the patient's disease duration or treatment regimen, it seems unlikely that this sufficiently explains all the observed differences, and that distinctly different gene signatures may indeed characterise different subsets of RA. Accordingly, it seems plausible that vitamin D deficiency may play slightly different roles in the aetiopathogenesis and progression of disease in different groups of patients. Ultimately, the role of vitamin D in RA appears far too complex to be understood through simple observational methods.

To date, studies of RA disease and vitamin D have focused on the link between RA and serum levels of the main circulating form of vitamin D, 25-OHD3. However, $25 \mathrm{OHD} 3$ is an inactive precursor for $1,25-(\mathrm{OH})_{2} \mathrm{D} 3$ and therefore has limited functional relevance for immunomodulation. Consequently, there has been a revival of interest in the role of other vitamin D metabolites both in serum and disease-affected synovial fluid as potentially more informative markers for vitamin D function in RA. Research on this subject began more than 25 years ago with seminal studies of vitamin D metabolism in RA tissues [125-127]. These reports indicated that concentrations of 25-OHD3 were significantly lower in synovial fluid relative to paired patient blood, but also revealed significant capacity for the generation of $1,25-(\mathrm{OH})_{2} \mathrm{D} 3$ by macrophages isolated from synovial fluid [127]. In more recent studies, we have measured multiple vitamin D metabolites-the vitamin D 'metabolome' in paired serum and synovial fluid from patients 


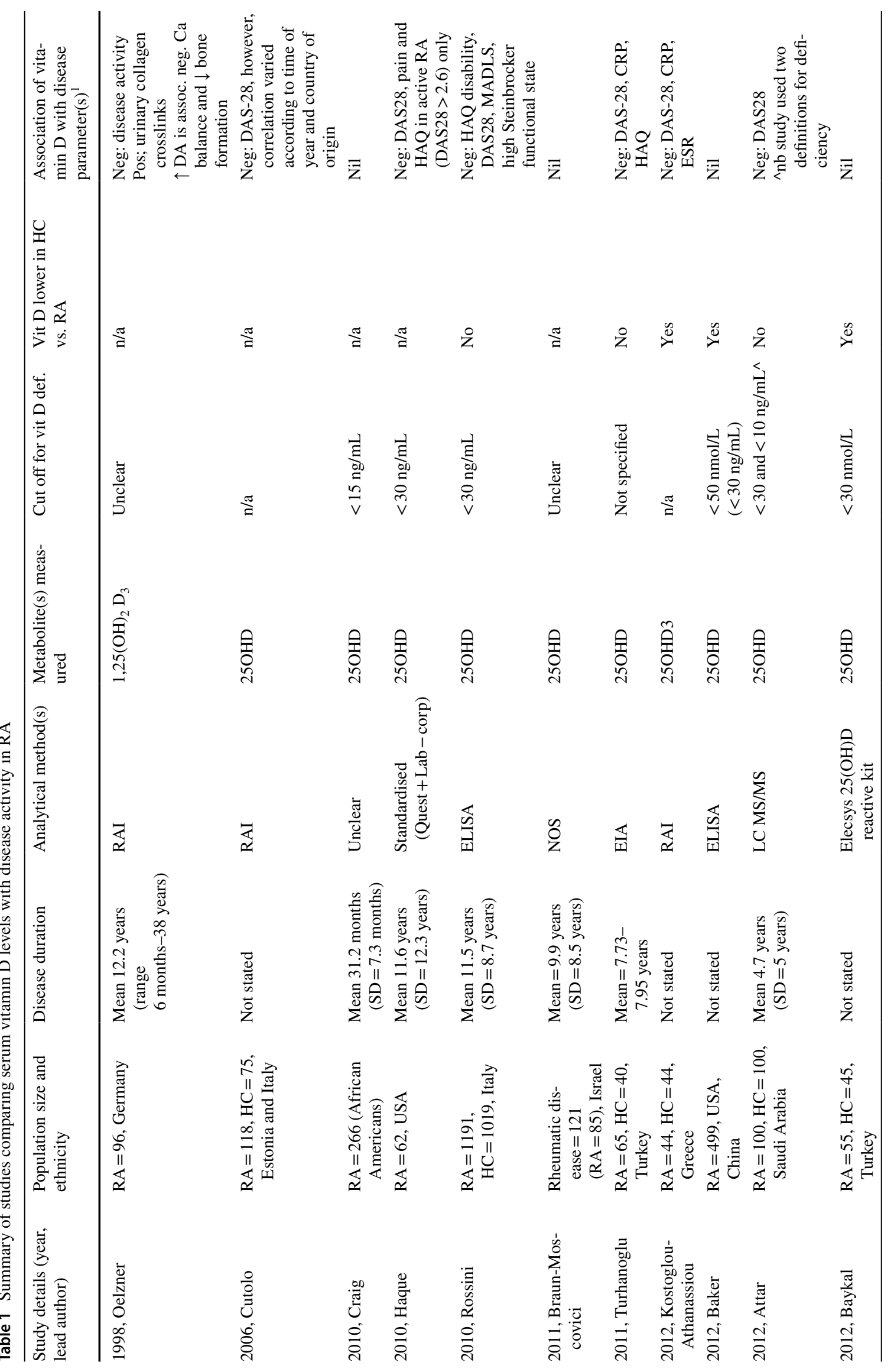




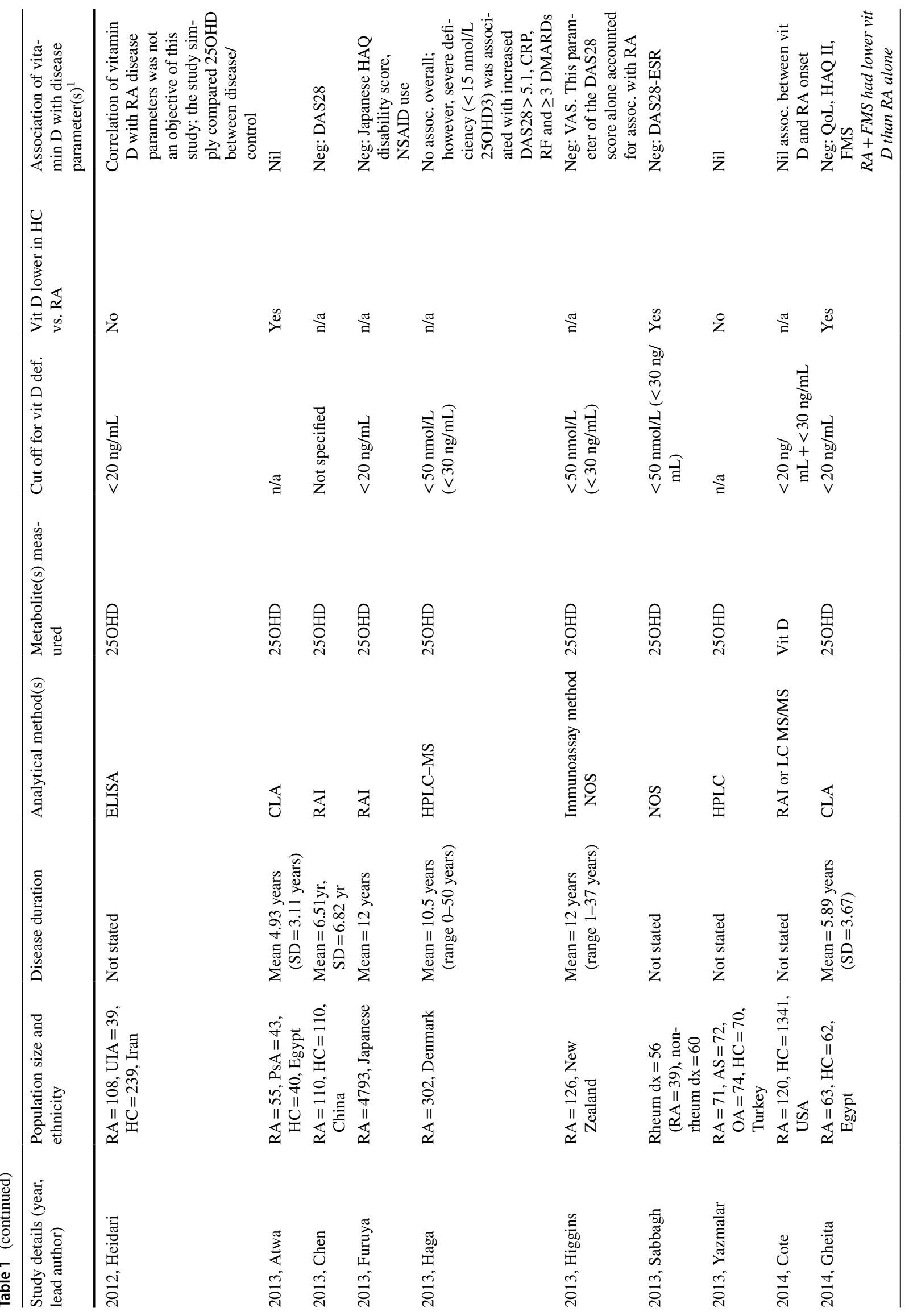




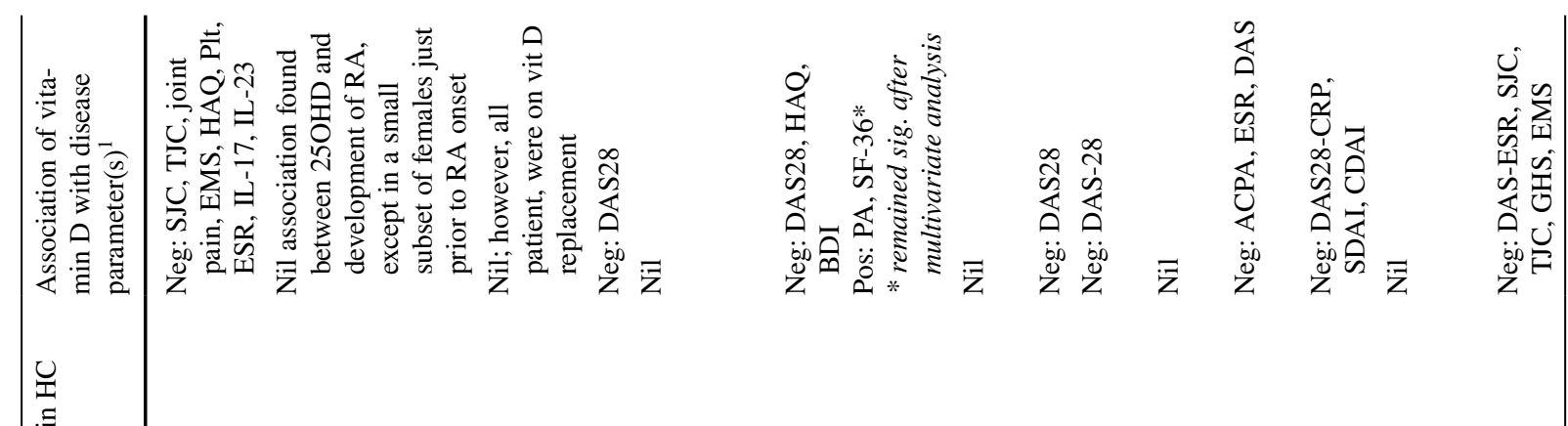

$$
\begin{aligned}
& \text { 离 }
\end{aligned}
$$

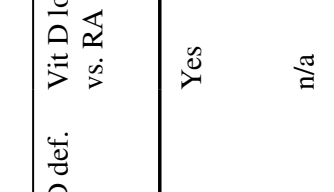

$$
\begin{aligned}
& \text {. } \\
& \text { 总 } \\
& \text { 辛 }
\end{aligned}
$$

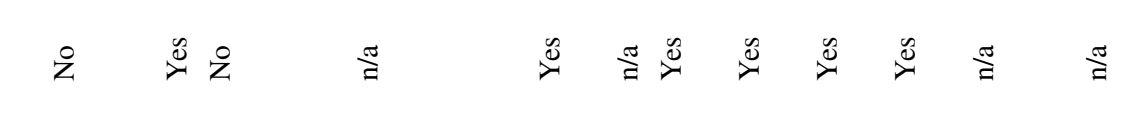

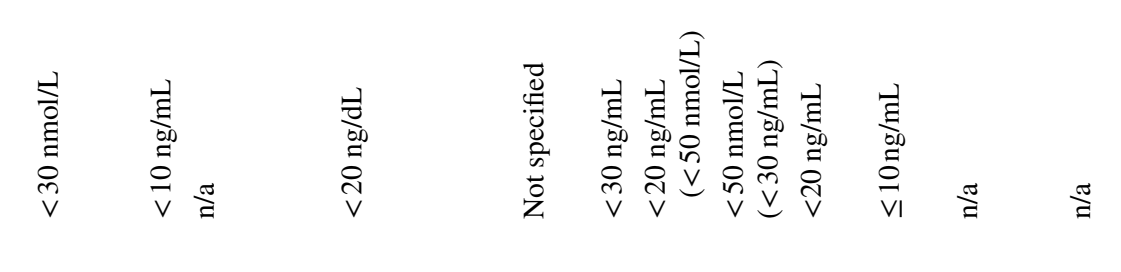

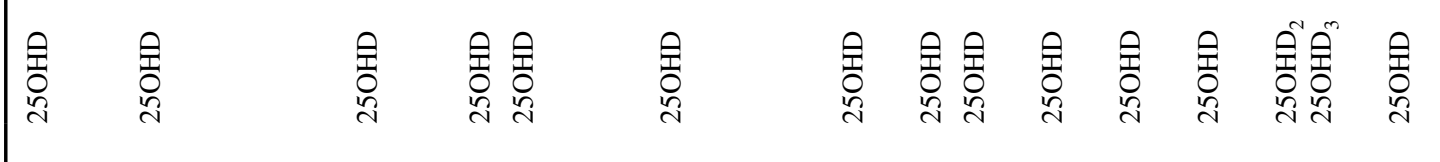

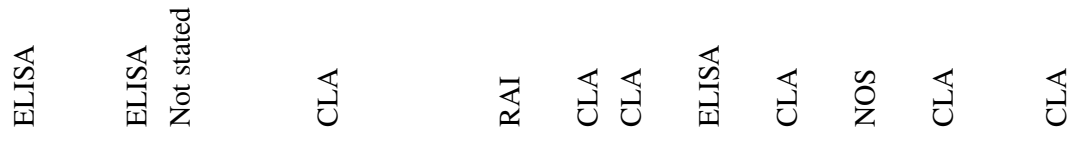

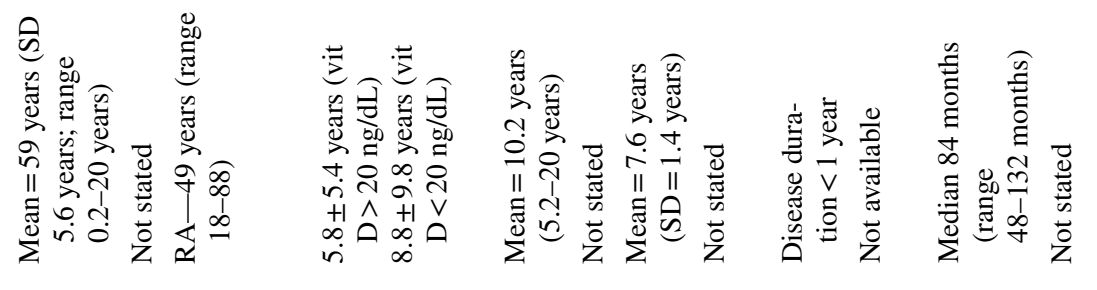

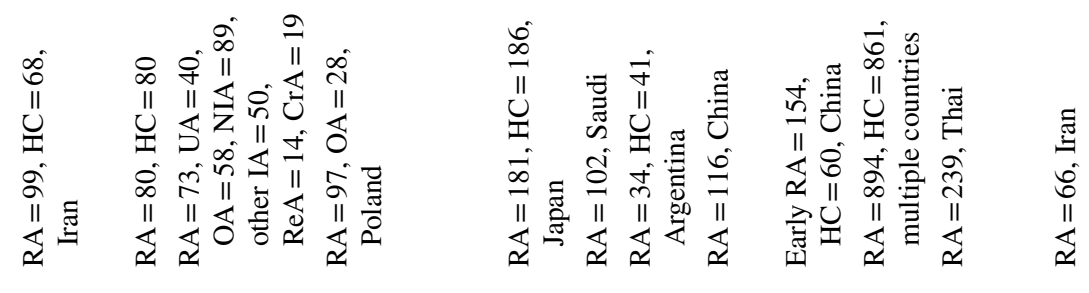

$$
\begin{aligned}
& \text { 离 } \\
& \text { 敢 } \\
& \text { 跣 }
\end{aligned}
$$

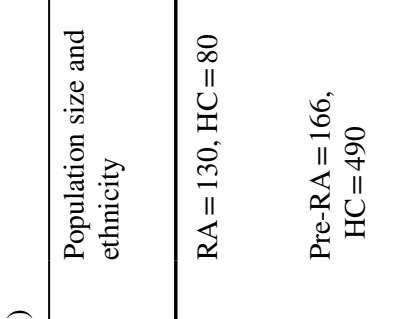

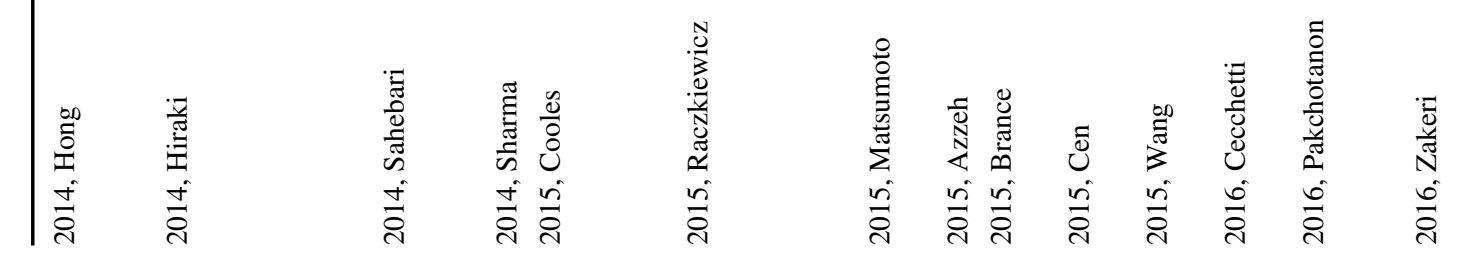




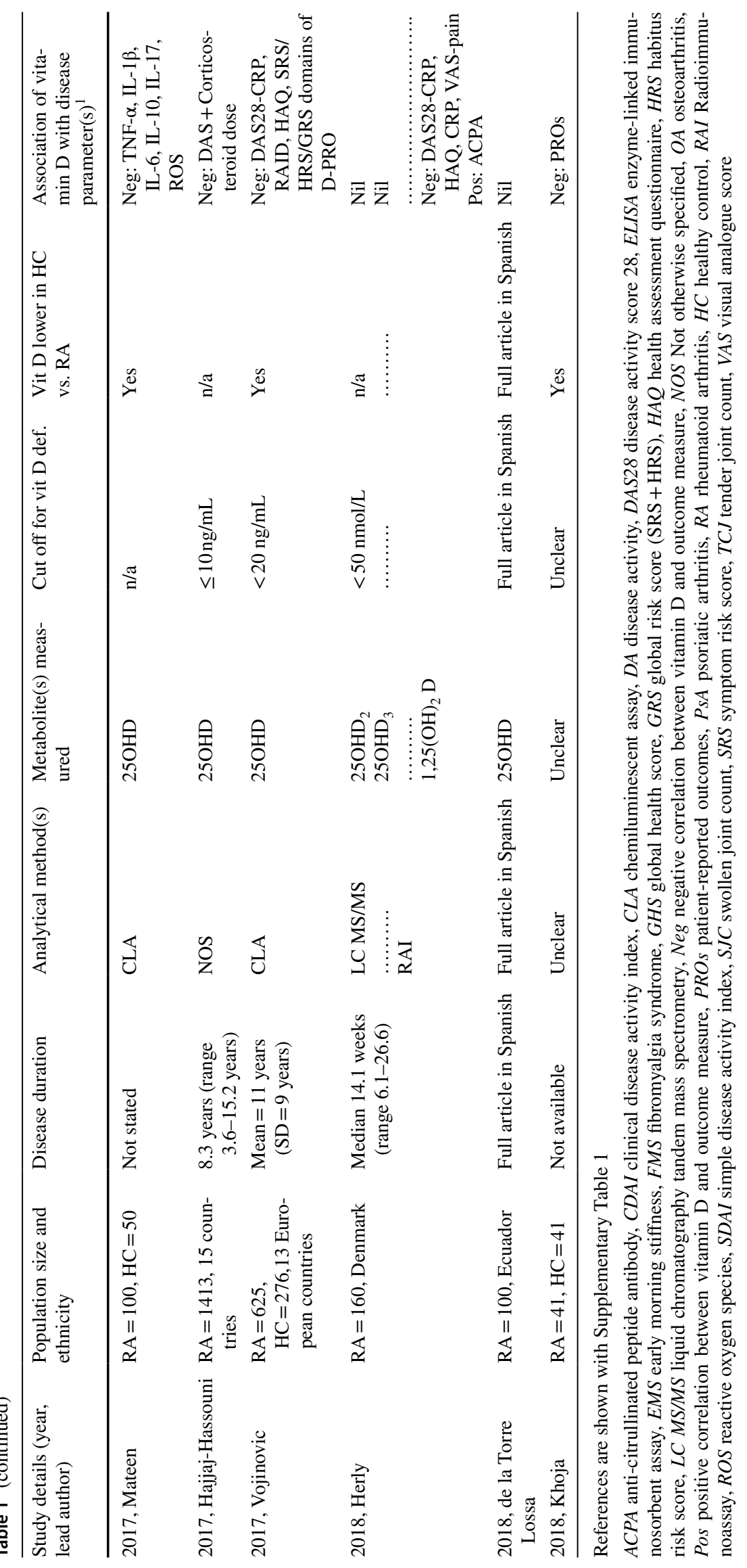


with established RA, reactive arthritis and healthy controls using the current gold standard for vitamin D analysis, liquid chromatography-tandem mass spectrometry (LC-MS/ MS) [128]. These studies showed that for markers such as swollen joint count (SJC), synovial fluid levels of vitamin D metabolites correlated better with RA disease activity than their circulating serum counterparts [128].

Another area of contention for vitamin D and RA concerns the definition of vitamin D deficiency itself (Table 1). In the UK, the National Institute of Clinical Excellence (NICE) recommends diagnosis of vitamin D deficiency when serum $25-\mathrm{OHD} 3$ is $<30 \mathrm{ng} / \mathrm{mL}$, and states that for some people $30-50 \mathrm{ng} / \mathrm{mL}$ may be insufficient, citing recommendations from the national osteoporosis society guidelines $[129,130]$. Hence, there appears to be an ambiguity around whether or not some patients need more vitamin D than others. Current NICE guidance does not define what constitutes adequate vitamin D status in patients of different ages, sex, ethnicities or disease states; for example, patients at risk of RA vs patients with established RA, or in other inflammatory diseases. To date, few studies have attempted to define what adequate supplementation means in RA. A cohort study published in 2012 observed that even supplementation 800-880 IU/day did not achieve adequate repletion of vitamin D (defined as $>20 \mathrm{ng} / \mathrm{mL}$ ) in $27.7 \%$ of RA patients who were vitamin D-deficient, although duration of therapy was not reported [131]. This suggests that different levels of vitamin D replacement may be required in different RA patients, depending on pre-supplementation of vitamin D levels, sunlight exposure and skin colour (darker skin absorbs less UV light to make vitamin D). Failure to adequately replete RA patients could also be related to poor treatment compliance or inadequate duration of supplementation. Importantly, inadequate repletion was related to higher HAQ scores for RA patients, implying that inadequate improvement of vitamin $\mathrm{D}$ status following supplementation had poorer outcomes [131]. Alternatively higher disease activity may simply be associated with less time spent outdoors, indirectly impacting sunlight exposure and skin synthesis of vitamin D. Further RCTs are needed to more clearly define the optimal levels of vitamin D for patients with RA, and how to achieve and maintain these levels. The next section of the review describes the reported supplementation trials for vitamin D and RA.

\section{Vitamin D Supplementation Trials in RA}

Ultimately, defining vitamin D deficiency in the context of RA is of clinical interest only if replacing vitamin $\mathrm{D}$ in RA patients who are deficient is likely to improve disease symptoms, or even prevent the onset of RA in those at risk. To date, vitamin D supplementation trials for RA have varied appreciably in terms of patient numbers, characteristics, disease duration and severity, concomitant medication regimen, type of/duration of supplementation regimen, number of outcomes and period over which these outcomes were measured (Table 2). A recent meta-analysis identified 9 RCTs of vitamin D supplementation for $\geq 3$ months in rheumatic diseases, including 5 studies of RA patients [132]. In RA, there was a decrease in the rate of disease flare, VAS and DAS-28 with vitamin D supplementation; however, all failed to reach statistical significance. Similar findings have also been reported in previous meta-analyses on this subject [133]. Conversely, a meta-analysis conducted in 2012 found that all but one of the 11 studies included in the metaanalysis suggested low vitamin D intake was linked with both increased risk of RA and greater disease activity [134]; however, the studies included in that analysis were cohort/ association by design, and not RCTs. Challenges associated with identifying whether vitamin D supplementation has a beneficial effect in RCTs to date include inter-study heterogeneity and relatively small sample numbers for a metaanalysis, with only 5 RCTs included, thus emphasising the need for larger RCTs in different subsets of RA patients to fully elucidate the role, if any, for vitamin D supplementation in the management of RA. In addition, there may be differences in vitamin D-binding protein levels, and other genetic variants, which influence the efficacy of vitamin D supplementation [135]. Vitamin D supplementation in low/ moderate doses is not thought to be harmful to patients, has wider health benefits, is relatively inexpensive and has fewer side effects/interactions compared with many other commonly used treatments for RA, such as non-steroidal anti-inflammatory drugs (NSAIDs), or conventional synthetic or biological disease-modifying anti-rheumatic drugs (DMARDs). Evidence is also emerging that vitamin D may augment certain therapies in RA. In one in vitro study, vitamin $\mathrm{D} 1,25-(\mathrm{OH})_{2} \mathrm{D} 3$ was shown to act synergistically with the biologic drug abatacept to inhibit $\mathrm{T}$ cell activation driven by anti-CD3 cross-linking, and promote a pro-regulatory CD28 phenotype [136]. The potential for enhancing the effects of biologics with simple, low-risk addition of $1,25-(\mathrm{OH})_{2} \mathrm{D} 3$ is interesting, and further work is required to validate this initial in vitro finding.

\section{Cellular Targets for Vitamin D in RA}

The pathogenesis of RA involves both innate and adaptive immune activities. Adaptive CD4+ T cells are critical in the pathogenesis of RA. For example, $T$ cells are a source of RANKL, leading to osteoclast activation and subsequent joint destruction in RA [137]. However, antigen-presenting cells (APCs) such as DC also contribute to RA by providing the necessary co-stimulatory signals required for CD4+ T cell activation $[138,139]$. Not only do APCs activate T cell proliferation, but they also influence $\mathrm{T}$ cell phenotype 


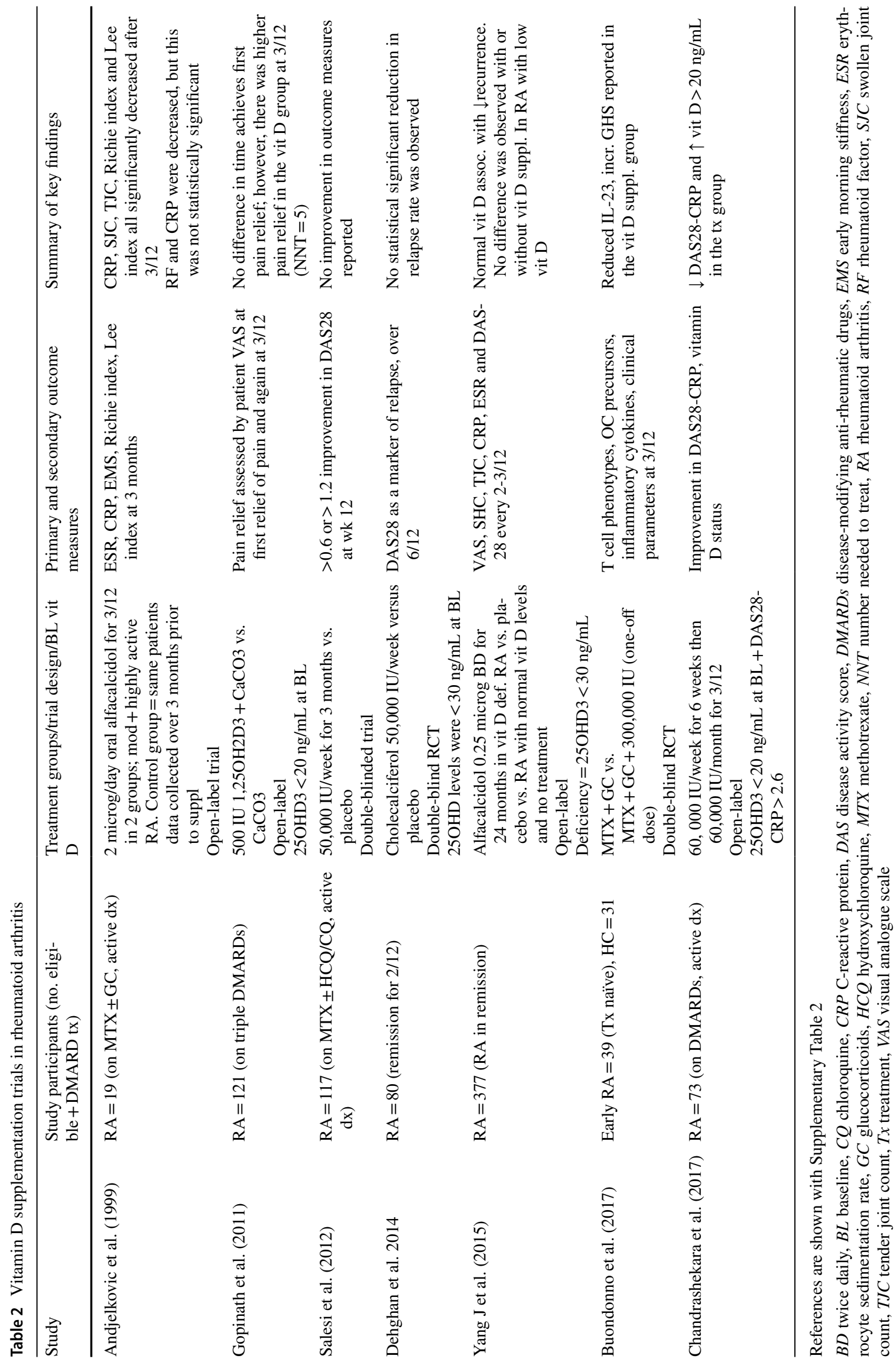


(Th1/Th2/Th17/Treg) and subsequent cytokine profile, and Th1/17 are both known to be relevant to the pathogenesis of RA [140, 141]. With this in mind, it is clear that the immunomodulatory activities of $1,25-(\mathrm{OH})_{2} \mathrm{D} 3$ described earlier in the review (see Fig. 1) have the potential to influence both the innate and adaptive immune cell types that contribute to the dysregulated immunity associated with RA. In a murine model of RA, tolerogenic DCs (tolDCs) were observed to reduce severity and progression of RA disease by increasing IL-10-producing T cell numbers and reducing Th17 cell counts [142]. It is therefore interesting to note that $1,25-(\mathrm{OH})_{2} \mathrm{D} 3$ can induce tolDC [143], and tolDCs, generated ex vivo using $1,25-(\mathrm{OH})_{2} \mathrm{D} 3$ have been proposed as a potential strategy for RA therapy [144]. In this instance, $1,25-(\mathrm{OH})_{2} \mathrm{D} 3$ was used in combination with the glucocorticoid dexamethasone which is known to promote a tolDC phenotype [58].

In addition to enhanced activity of Th1 and Th17 cells, RA disease is also characterised by reduced Treg activity, including decreased Treg numbers [145], a reduction in Treg: Th1/Th17 ratio [146], altered Treg function [147] and differences in Treg number and function in the peripheral blood compared with the synovium [148]. However, in some studies, numbers of circulating Treg in RA were similar to those found in healthy controls [149] and osteoarthritis patients [150]. Tregs are likely to be a key target for vitamin D in RA. In animal models of experimental autoimmune encephalitis (the most widely used mouse model of MS), IBD and T1D, 1,25- $(\mathrm{OH})_{2} \mathrm{D} 3$ promotes a Treg phenotype and augment IL-10 production, thus inhibiting Th17 responses and ameliorating disease [54]. In studies using human Tregs, the 1,25-(OH) $)_{2} \mathrm{D} 3$ analogue TX527 skewed the Treg cell phenotype in favour of migration to sites of inflammation [151], whilst also promoting a stable Treg phenotype [152]. The growing pool of ex vivo and in vitro evidence linking vitamin $\mathrm{D}$ and Treg function now requires replication in vivo, particularly in diseases such as RA.

To date, most studies of the $\mathrm{T}$ cell actions of 1,25$(\mathrm{OH})_{2} \mathrm{D} 3$ have been based on the analysis of mixed populations of circulating $\mathrm{T}$ cells from healthy donors. However, in recent studies, we have shown that $\mathrm{T}$ cells from synovial fluid of RA patients' inflamed joints are relatively insensitive to $1,25-(\mathrm{OH})_{2} \mathrm{D} 3$, despite expressing the VDR machinery required for $1,25-(\mathrm{OH})_{2} \mathrm{D} 3$ signalling [153]. This is due, in part, to decreased $1,25-(\mathrm{OH})_{2} \mathrm{D} 3$ responsiveness in the memory $\mathrm{T}$ cells that predominate in RA synovial fluid, but also involves tissue-specific effects, with synovial fluid memory $\mathrm{T}$ cells showing decreased responses to $1,25-(\mathrm{OH})_{2} \mathrm{D} 3$ relative to peripheral blood memory $\mathrm{T}$ cells [153]. Based on these observations, we have proposed that immunomodulatory responses to vitamin $\mathrm{D}$ at tissue sites of inflammation are impaired by target cell insensitivity to $1,25-(\mathrm{OH})_{2} \mathrm{D} 3$. If this is the case, then conventional analysis of the effects of vitamin D using circulating blood immune cells can only provide a limited picture of immunomodulation by vitamin $\mathrm{D}$ in diseases such as RA. Likewise, to overcome the vitamin D-insensitivity observed in RA patient, inflamed joints may require alternative strategies. This could include the use of higher doses of vitamin $\mathrm{D}$ supplements to enhance localised tissue levels of $1,25-(\mathrm{OH})_{2} \mathrm{D} 3$, or the use of vitamin $\mathrm{D}$ as an adjunct to other RA therapies. With respect to the latter, we have recently shown that $1,25-(\mathrm{OH})_{2} \mathrm{D} 3$ can more potently inhibit $\mathrm{T}$ cell activation when used in combination with the CD28 co-stimulatory blocker abatacept [154].

Beyond the actions of innate and adaptive immune cells, synovial fibroblasts (synoviocytes) also play an important role in the pathogenesis of RA. In studies using the immortalised synoviocyte cell line, MH7A, 1,25- $(\mathrm{OH})_{2} \mathrm{D} 3$ has been shown to promote synoviocyte apoptosis, which might protect against RA, but only when cells were treated with both tumor necrosis factor $\alpha(\mathrm{TNF} \alpha)$ and $1,25-(\mathrm{OH})_{2} \mathrm{D} 3$ [155]. These observations suggest that TNF $\alpha$ is required for $1,25-(\mathrm{OH})_{2} \mathrm{D} 3$ to have anti-inflammatory effects in RA, which is a paradoxical observation given the use of TNF $\alpha$ inhibitors as biological treatment in RA. Conversely, other studies have reported synergistic effects of TNF $\alpha$ inhibition and $1,25-(\mathrm{OH})_{2} \mathrm{D} 3$ in suppressing Th17-mediated inflammation [156], suggesting a complex interaction between TNF $\alpha$ and 1,25-(OH $)_{2} \mathrm{D} 3$. Other studies using MH7A cells have shown synergistic effects of interleukin $1 \beta$ (IL-1 $\beta$ ) and $1,25-(\mathrm{OH})_{2} \mathrm{D} 3$ in suppressing the production of IL-6 and TNF $\beta$ levels, and Th17-inducing cytokines (IL-1 $\beta$, IL-6 and IL-23) synergistically enhanced the pro-regulatory effect of 1,25-(OH $)_{2} \mathrm{D} 3$ on T cell phenotype [136], further emphasising important interactions between $1,25-(\mathrm{OH})_{2} \mathrm{D} 3$ and pro-inflammatory cytokines in RA [157]. Collectively, these observations suggest that the beneficial effects of 1,25$(\mathrm{OH})_{2} \mathrm{D} 3$ are most potent when the threshold for activation of the immune response is breached, leading to concomitant production of inflammatory cytokines. Therefore, in the setting of inflammation, vitamin D appears to function as a negative-feedback regulator, attenuating the inflammatory immune responses. Vitamin D may also influence the synovial microenvironment by modulating factors that influence joint bone and cartilage damage. In studies using synoviocytes and articular chondrocytes from RA patients, 1,25$(\mathrm{OH})_{2} \mathrm{D} 3$ was shown to regulate matric metalloproteinases and prostaglandins, but only in the presence of IL-1 $\beta$ [158], suggesting, as outlined earlier, that $1,25-(\mathrm{OH})_{2} \mathrm{D} 3$ is only effective as a regulator of synoviocytes in the setting of RA disease inflammation. 


\section{Conclusions}

Future studies of vitamin D and RA are needed firstly to expand our current understanding of the mechanisms by which $1,25-(\mathrm{OH})_{2} \mathrm{D} 3$ is able to regulate key cells associated with RA. In particular, the observation that $\mathrm{T}$ cells from the inflamed joints of RA patients are insensitive to $1,25-(\mathrm{OH})_{2} \mathrm{D} 3$ [153] indicates that RA disease is associated with a corruption of vitamin $\mathrm{D}$ signalling that may be fundamentally important for RA disease pathology, and the therapeutic use of vitamin D. A key question that remains to be answered is whether vitamin $D$ has greater benefits in protecting against the onset of RA as opposed to its potential application as a therapy for established RA disease. Thus, future studies to assess the effects of vitamin D supplementation on disease prevention in individuals at risk of RA, and disease development in those at early stages of RA, are required. These studies are likely to be informed by recent meta-analyses for immune effects of vitamin D. Notably, the observation from the analysis of acute respiratory infection trials that vitamin D supplementation was more beneficial in patients with low baseline serum vitamin $\mathrm{D}$, and was more effective when supplementation was used as lower daily or weekly dosing [159], provides some important pointers for future studies of vitamin D and RA. Repeated lower doses of vitamin $\mathrm{D}$ supplementation would also help to avoid potential adverse effects of higher doses of vitamin D, in particular the reported increased risk of falls in elderly patients receiving a single bolus of higher-dose vitamin D [160]. Future studies also need to take into consideration clinical subgroups of patients, including distinguishing between ethnic groups and disease of different durations. The potential for a simple, low-risk and low-cost intervention such as vitamin D as a plausible adjunctive treatment for RA is an exciting notion. Robust evidence to support wider routine use of vitamin D supplementation in RA has the potential to significantly enhance treatment for RA and other autoimmune diseases.

Funding Funding was provided by Royal Society (Grant No. WM130118), National Institutes of Health Research (Grant No. Birmingham Biomedical Research Centre), Medical Research Council (Grant No. PhD Studentship).

\section{Compliance with Ethical Standards}

Conflict of interest Stephanie R. Harrison, Danyang Li, Louisa E. Jefery, Karim Raza, and Martin Hewison declare that they have no conflict of interest.

Open Access This article is distributed under the terms of the Creative Commons Attribution 4.0 International License (http://creativeco mmons.org/licenses/by/4.0/), which permits unrestricted use, distribution, and reproduction in any medium, provided you give appropriate credit to the original author(s) and the source, provide a link to the Creative Commons license, and indicate if changes were made.

\section{References}

1. Christakos S, Ajibade D, Dhawan P, Fechner A, Mady L (2011) Vitamin D: metabolism. Endocrinol Metab 39:243-253

2. DeLuca HF (2014) History of the discovery of vitamin D and its active metabolites. BoneKEy Rep 3:1-8

3. Christakos S, Hewison M, Gardner DG, Wagner CL, Sergeev IN, Rutten E, Pittas AG, Boland R, Ferrucci L, Bikle DD (2013) Vitamin D: beyond bone. Ann N Y Acad Sci 1287:45-58

4. Mathieu C (2015) Vitamin D and diabetes: where do we stand? Diabetes Res Clin Pract 108:201-209

5. Bizzaro G, Shoenfeld Y (2015) Vitamin D and autoimmune thyroid diseases: facts and unresolved questions. Immunol Res 61:46-52

6. Kivity S, Agmon-Levin N, Zisappl M, Shapira Y, Nagy EV, Danko K, Szekanecz Z, Langevitz P, Shoenfeld Y (2011) Vitamin D and autoimmune thyroid diseases. Cell Mol Immunol $8: 243-247$

7. Cantorna MT (2012) Vitamin D, multiple sclerosis and inflammatory bowel disease. Arch Biochem Biophys 523:103-106

8. Cutolo M, Otsa K (2008) Review: vitamin D, immunity and lupus. Lupus 17:6-10

9. Jeffery LE, Raza K, Hewison M (2016) Vitamin D in rheumatoid arthritis-towards clinical application. Nat Rev Rheumatol $12: 201-210$

10. Zhu JG, Ochalek JT, Kaufmann M, Jones G, Deluca HF (2013) CYP2R1 is a major, but not exclusive, contributor to 25-hydroxyvitamin D production in vivo. Proc Natl Acad Sci USA 110:15650-15655

11. Hewison M, Zehnder D, Bland R, Stewart PM (2000) 1alphaHydroxylase and the action of vitamin D. J Mol Endocrinol 25:141-148

12. Zehnder D, Bland R, Williams MC, McNinch RW, Howie AJ, Stewart PM, Hewison M (2001) Extrarenal expression of 25-hydroxyvitamin d(3)-1 alpha-hydroxylase. J Clin Endocrinol Metab 86:888-894

13. Hewison M, Freeman L, Hughes SV, Evans KN, Bland R, Eliopoulos AG, Kilby MD, Moss PA, Chakraverty R (2003) Differential regulation of vitamin $\mathrm{D}$ receptor and its ligand in human monocyte-derived dendritic cells. J Immunol 170:5382-5390

14. Kreutz M, Andreesen R, Krause SW, Szabo A, Ritz E, Reichel $H$ (1993) 1,25-dihydroxyvitamin D3 production and vitamin D3 receptor expression are developmentally regulated during differentiation of human monocytes into macrophages. Blood 82:1300-1307

15. Jeffery LE, Wood AM, Qureshi OS, Hou TZ, Gardner D, Briggs Z, Kaur S, Raza K, Sansom DM (2012) Availability of 25-hydroxyvitamin D3 to APCs controls the balance between regulatory and inflammatory $\mathrm{T}$ cell responses. J Immunol 189:5155-5164

16. Hewison M, Burke F, Evans KN, Lammas DA, Sansom DM, Liu P, Modlin RL, Adams JS (2007) Extra-renal 25-hydroxyvitamin D3-1alpha-hydroxylase in human health and disease. J Steroid Biochem Mol Biol 103:316-321

17. Hewison $M(2010)$ Vitamin $D$ and the intracrinology of innate immunity. Mol Cell Endocrinol 321:103-111

18. Hewison M (2010) Vitamin D and the intracrinology of innate immunity. Mol Cell Endocrinol 321:103-111 
19. Adams JS, Rafison B, Witzel S, Reyes RE, Shieh A, Chun R, Zavala K, Hewison M, Liu PT (2014) Regulation of the extrarenal CYP27B1-hydroxylase. J Steroid Biochem Mol Biol 144:22-27

20. Chun RF, Peercy BE, Orwoll ES, Nielson CM, Adams JS, Hewison M (2014) Vitamin D and DBP: the free hormone hypothesis revisited. J Steroid Biochem Mol Biol 144(Pt A):132-137

21. Chun RF, Lauridsen AL, Suon L, Zella LA, Pike JW, Modlin RL, Martineau AR, Wilkinson RJ, Adams J, Hewison M (2010) Vitamin D-binding protein directs monocyte responses to 25-hydroxy- and 1,25-dihydroxyvitamin D. J Clin Endocrinol Metab 95:3368-3376

22. Jones G, Prosser DE, Kaufmann M (2012) 25-Hydroxyvitamin D-24-hydroxylase (CYP24A1): its important role in the degradation of vitamin D. Arch Biochem Biophys 523:9-18

23. Schlingmann KP, Kaufmann M, Weber S, Irwin A, Goos C, John U, Misselwitz J, Klaus G, Kuwertz-Broking E, Fehrenbach H, Wingen AM, Guran T, Hoenderop JG, Bindels RJ, Prosser DE, Jones G, Konrad M (2011) Mutations in CYP24A1 and idiopathic infantile hypercalcemia. N Engl J Med 365:410-421

24. Adams JS, Hewison M (2008) Unexpected actions of vitamin D: new perspectives on the regulation of innate and adaptive immunity. Nat Clin Pract Endocrinol Metab 4:80-90

25. Hewison M (2011) Vitamin D and innate and adaptive immunity. Vitam Horm 86:23-62

26. Hewison M (2011) Antibacterial effects of vitamin D. Nat Rev 7:337-345

27. Wang Y, Zhu J, DeLuca HF (2012) Where is the vitamin D receptor? Arch Biochem Biophys 523:123-133

28. Bouillon R, Carmeliet G, Verlinden L, van Etten E, Verstuyf A, Luderer HF, Lieben L, Mathieu C, Demay M (2008) Vitamin D and human health: lessons from vitamin $\mathrm{D}$ receptor null mice. Endocr Rev 29:726-776

29. Zhang Y-G, Wu S, Lu R, Zhou D, Zhou J, Carmeliet G, Petrof E, Claud EC, Sun J (2015) Tight junction CLDN2 gene is a direct target of the vitamin D receptor. Sci Rep 5:10642

30. He L, Liu T, Shi Y, Tian F, Hu H, Deb DK, Chen Y, Bissonnette M, Li YC (2018) Gut epithelial vitamin d receptor regulates microbiota-dependent mucosal inflammation by suppressing intestinal epithelial cell apoptosis. Endocrinology 159:967-979

31. Wang TT, Dabbas B, Laperriere D, Bitton AJ, Soualhine H, Tavera-Mendoza LE, Dionne S, Servant MJ, Bitton A, Seidman EG, Mader S, Behr MA, White JH (2010) Direct and indirect induction by 1,25 -dihydroxyvitamin D3 of the NOD2/CARD15defensin beta2 innate immune pathway defective in Crohn disease. J Biol Chem 285:2227-2231

32. Bacchetta J, Zaritsky JJ, Sea JL, Chun RF, Lisse TS, Zavala K, Nayak A, Wesseling-Perry K, Westerman M, Hollis BW, Salusky IB, Hewison M (2014) Suppression of iron-regulatory hepcidin by vitamin D. J Am Soc Nephrol 25:564-572

33. Liu PT, Stenger S, Li H, Wenzel L, Tan BH, Krutzik SR, Ochoa MT, Schauber J, Wu K, Meinken C, Kamen DL, Wagner M, Bals R, Steinmeyer A, Zugel U, Gallo RL, Eisenberg D, Hewison M, Hollis BW, Adams JS, Bloom BR, Modlin RL (2006) Toll-like receptor triggering of a vitamin $\mathrm{D}$-mediated human antimicrobial response. Science 311:1770-1773

34. Liu PT, Schenk M, Walker VP, Dempsey PW, Kanchanapoomi M, Wheelwright M, Vazirnia A, Zhang X, Steinmeyer A, Zugel U, Hollis BW, Cheng G, Modlin RL (2009) Convergence of IL1 beta and VDR activation pathways in human TLR2/1-induced antimicrobial responses. PLoS ONE 4:e5810

35. Kim TH, Lee B, Kwon E, Choi SJ, Lee YH, Song GG, Sohn J, Ji JD (2013) Regulation of TREM-1 expression by 1,25-dihydroxyvitamin D3 in human monocytes/macrophages. Immunol Lett 154:80-85
36. Sadeghi K, Wessner B, Laggner U, Ploder M, Tamandl D, Friedl J, Zugel U, Steinmeyer A, Pollak A, Roth E, Boltz-Nitulescu G, Spittler A (2006) Vitamin D3 down-regulates monocyte TLR expression and triggers hyporesponsiveness to pathogen-associated molecular patterns. Eur J Immunol 36:361-370

37. Meyer V, Saccone DS, Tugizimana F, Asani FF, Jeffery TJ, Bornman L (2017) Methylation of the Vitamin D Receptor (VDR) gene, together with genetic variation, race, and environment influence the signaling efficacy of the toll-like receptor 2/1-VDR pathway. Front Immunol 8:1-15

38. Fritsche J, Mondal K, Ehrnsperger A, Andreesen R, Kreutz M (2003) Regulation of 25-hydroxyvitamin D3-1 alpha-hydroxylase and production of 1 alpha,25-dihydroxyvitamin D3 by human dendritic cells. Blood 102:3314-3316

39. Dionne S, Duchatelier CF, Seidman EG (2017) The influence of vitamin D on M1 and M2 macrophages in patients with Crohn's disease. Innate Immun 23:557-565

40. Hewison M, Zehnder D, Chakraverty R, Adams JS (2004) Vitamin D and barrier function: a novel role for extra-renal 1 alphahydroxylase. Mol Cell Endocrinol 215:31-38

41. Penna G, Adorini L (2000) 1 Alpha, 25-dihydroxyvitamin D3 inhibits differentiation, maturation, activation, and survival of dendritic cells leading to impaired alloreactive $\mathrm{T}$ cell activation. J Immunol (Baltimore, Md.: 1950) 164:2405-2411

42. van Halteren AG, Tysma OM, van Etten E, Mathieu C, Roep BO (2004) 1alpha,25-dihydroxyvitamin D3 or analogue treated dendritic cells modulate human autoreactive $T$ cells via the selective induction of apoptosis. J Autoimmun 23:233-239

43. Pedersen AW, Holmstrøm K, Jensen SS, Fuchs D, Rasmussen S, Kvistborg P, Claesson MH, Zocca MB (2009) Phenotypic and functional markers for $1 \alpha, 25$-dihydroxyvitamin D3-modified regulatory dendritic cells. Clin Exp Immunol 157:48-59

44. Griffin MD, Lutz W, Phan VA, Bachman LA, McKean DJ, Kumar R (2001) Dendritic cell modulation by 1alpha,25 dihydroxyvitamin D3 and its analogs: a vitamin D receptor-dependent pathway that promotes a persistent state of immaturity in vitro and in vivo. Proc Natl Acad Sci USA 98:6800-6805

45. Willheim M, Thien R, Schrattbauer K, Bajna E, Holub M, Gruber R, Baier K, Pietschmann P, Reinisch W, Scheiner O, Peterlik M (1999) Regulatory effects of 1alpha,25-dihydroxyvitamin D3 on the cytokine production of human peripheral blood lymphocytes. J Clin Endocrinol Metab 84:3739-3744

46. Bartels LE, Jørgensen SP, Agnholt J, Kelsen J, Hvas CL, Dahlerup JF (2007) 1,25-dihydroxyvitamin D3 and dexamethasone increase interleukin-10 production in CD4+ $\mathrm{T}$ cells from patients with Crohn's disease. Int Immunopharmacol 7:1755-1764

47. Penna G, Adorini L (2000) 1,25-dihydroxyvitamin D3 inhibits differentiation, maturation, activation, and survival of dendritic cells leading to impaired alloreactive T cell activation. J Immunol 164:2405-2411

48. Piemonti L, Monti P, Sironi M, Fraticelli P, Leone BE, Dal Cin E, Allavena P, Di Carlo V (2000) Vitamin D3 affects differentiation, maturation, and function of human monocyte-derived dendritic cells. J Immunol (Baltimore, Md.: 1950) 164:4443-4451

49. Szeles L, Keresztes G, Torocsik D, Balajthy Z, Krenacs L, Poliska S, Steinmeyer A, Zuegel U, Pruenster M, Rot A, Nagy L (2009) 1,25-dihydroxyvitamin D3 is an autonomous regulator of the transcriptional changes leading to a tolerogenic dendritic cell phenotype. J Immunol (Baltimore, Md.: 1950) 182:2074-2083

50. Bhalla AK, Amento EP, Clemens TL, Holick MF, Krane SM (1983) Specific high-affinity receptors for 1,25-dihydroxyvitamin D3 in human peripheral blood mononuclear cells: presence in monocytes and induction in $\mathrm{T}$ lymphocytes following activation. J Clin Endocrinol Metab 57:1308-1310

51. Provvedini DM, Tsoukas CD, Deftos LJ, Manolagas SC (1986) 1 alpha,25-Dihydroxyvitamin D3-binding macromolecules in 
human B lymphocytes: effects on immunoglobulin production. J Immunol 136:2734-2740

52. Hewison M (2012) Vitamin D and immune function: an overview. Proc Nutr Soc 71:50-61

53. Sarkar S, Hewison M, Studzinski GP, Li YC, Kalia V (2016) Role of vitamin D in cytotoxic T lymphocyte immunity to pathogens and cancer. Crit Rev Clin Lab Sci 53:132-145

54. Cantorna MT, Snyder L, Lin Y-D, Yang L (2015) Vitamin D and 1,25(OH)2D regulation of T cells. Nutrients 7:3011-3021

55. Joshi S, Pantalena LC, Liu XK, Gaffen SL, Liu H, RohowskyKochan C, Ichiyama K, Yoshimura A, Steinman L, Christakos S, Youssef S (2011) 1,25-dihydroxyvitamin D(3) ameliorates Th17 autoimmunity via transcriptional modulation of interleukin-17A. Mol Cell Biol 31:3653-3669

56. Cantorna MT, Nashold FE, Chun TY, Hayes CE (1996) Vitamin A down-regulation of IFN-gamma synthesis in cloned mouse Th1 lymphocytes depends on the CD28 costimulatory pathway. J Immunol 156:2674-2679

57. Boonstra A, Barrat FJ, Crain C, Heath VL, Savelkoul HF, O'Garra A (2001) 1alpha,25-Dihydroxyvitamin d3 has a direct effect on naive CD4(+) T cells to enhance the development of Th2 cells. J Immunol 167:4974-4980

58. Barrat FJ, Cua DJ, Boonstra A, Richards DF, Crain C, Savelkoul HF, de Waal-Malefyt R, Coffman RL, Hawrylowicz CM, O'Garra A (2002) In vitro generation of interleukin 10-producing regulatory $\mathrm{CD} 4(+) \mathrm{T}$ cells is induced by immunosuppressive drugs and inhibited by Thelper type 1 (Th1)- and Th2-inducing cytokines. J Exp Med 195:603-616

59. Jeffery LE, Burke F, Mura M, Zheng Y, Qureshi OS, Hewison M, Walker LS, Lammas DA, Raza K, Sansom DM (2009) 1,25-Dihydroxyvitamin D3 and IL-2 combine to inhibit T cell production of inflammatory cytokines and promote development of regulatory T cells expressing CTLA-4 and FoxP3. J Immunol 183:5458-5467

60. von Essen MR, Kongsbak M, Schjerling P, Olgaard K, Odum N, Geisler C (2010) Vitamin D controls T cell antigen receptor signaling and activation of human T cells. Nat Immunol 11:344-349

61. Merino F, Alvarez-Mon M, de la Hera A, Ales JE, Bonilla F, Durantez A (1989) Regulation of natural killer cytotoxicity by 1,25-dihydroxyvitamin D3. Cell Immunol 118:328-336

62. Yu S, Cantorna MT (2008) The vitamin D receptor is required for iNKT cell development. Proc Natl Acad Sci USA 105:5207-5212

63. Muller K, Heilmann C, Poulsen LK, Barington T, Bendtzen K (1991) The role of monocytes and T cells in 1,25-dihydroxyvitamin D3 mediated inhibition of B cell function in vitro. Immunopharmacology 21:121-128

64. Chen S, Sims GP, Chen XX, Gu YY, Chen S, Lipsky PE (2007) Modulatory effects of 1,25-dihydroxyvitamin D3 on human B cell differentiation. J Immunol 179:1634-1647

65. Heine G, Niesner U, Chang HD, Steinmeyer A, Zugel U, Zuberbier T, Radbruch A, Worm M (2008) 1,25-dihydroxyvitamin $\mathrm{D}$ (3) promotes IL-10 production in human B cells. Eur J Immunol 38:2210-2218

66. Shirakawa AK, Nagakubo D, Hieshima K, Nakayama T, Jin Z, Yoshie O (2008) 1,25-Dihydroxyvitamin D3 induces CCR16 expression in terminally differentiating human B cells. J Immunol 180:2786-2795

67. Hufnaql K, Jensen-Jarolim E (2018) Vitamin A and D in allergy: from experimental animal models and cellular studies to human disease. Allergo J Int 27:72-78

68. Anaya JM, Restrepo-Jiménez P, Ramírez-Santana C (2018) The autoimmune ecology: an update. Curr Opin Rheumatol 30:350-360
69. Nikiphorou E, Uksila J, Sokka T (2018) A cross-sectional study of vitamin D levels in a large cohort of patients with rheumatic diseases. Clin Rheumatol 37:803-810

70. Lucas R, Rodney Harris R (2018) On the nature of evidence and 'proving' causality: smoking and lung cancer vs. sun exposure, vitamin D and multiple sclerosis. Int J Environ Res Public Health 15:1726

71. Disanto G, Chaplin G, Morahan JM, Giovannoni G, Hypponen E, Ebers GC, Ramagopalan SV (2012) Month of birth, vitamin $\mathrm{D}$ and risk of immune-mediated disease: a case control study. BMC Med 10:69

72. Harroud A, Richards JB (2018) Mendelian randomization in multiple sclerosis: a causal role for vitamin D and obesity? Mult Scler 24:80-85

73. Mokry LE, Ross S, Ahmad OS, Forgetta V, Smith GD, Goltzman D, Leong A, Greenwood CM, Thanassoulis G, Richards JB (2015) Vitamin D and risk of multiple sclerosis: a mendelian randomization study. PLoS Med 12:e1001866

74. Krementsov DN, Asarian L, Fang Q, McGill MM, Teuscher C (2018) Sex-specific gene-by-vitamin D interactions regulate susceptibility to central nervous system autoimmunity. Front Immunol 9:1-15

75. Kamisli O, Acar C, Sozen M, Tecellioglu M, Yücel FE, Vaizoglu D, Özcan C (2018) The association between vitamin D receptor polymorphisms and multiple sclerosis in a Turkish population. Mult Scler Relat Disord 20:78-81

76. Kř̌enek P, Benešová $Y$, Bienertová-Vašků J, Vašků A (2018) The impact of five VDR polymorphisms on multiple sclerosis risk and progression: a case-control and genotype-phenotype study. J Mol Neurosci 64:559-566

77. Kouchaki E, Afarini M, Abolhassani J, Mirhosseini N, Bahmani F, Masoud SA, Asemi Z (2018) High-dose $\omega-3$ fatty acid plus vitamin D3 supplementation affects clinical symptoms and metabolic status of patients with multiple sclerosis: a randomized controlled clinical trial. J Nutr 148:1380-1386

78. Rolf L, Muris AG, Theunissen R, Hupperts R, Damoiseaux J, Smolders J (2018) Vitamin D3 supplementation and the IL-2/ IL-2R pathway in multiple sclerosis: attenuation of progressive disturbances? J Neuroimmunol 314:50-57

79. Miclea A, Miclea M, Pistor M, Hoepner A, Chan A, Hoepner R (2017) Vitamin D supplementation differentially affects seasonal multiple sclerosis disease activity. Brain Behav 7:e00761

80. Rosjo E, Lossius A, Abdelmagid N, Lindstrom JC, Kampman MT, Jorgensen L, Sundstrom P, Olsson T, Steffensen LH, Torkildsen O, Holmoy T (2017) Effect of high-dose vitamin D3 supplementation on antibody responses against EpsteinBarr virus in relapsing-remitting multiple sclerosis. Mult Scler 23:395-402

81. Rosjo E, Steffensen LH, Jorgensen L, Lindstrom JC, Saltyte Benth J, Michelsen AE, Aukrust P, Ueland T, Kampman MT, Torkildsen O, Holmoy T (2015) Vitamin D supplementation and systemic inflammation in relapsing-remitting multiple sclerosis. J Neurol 262:2713-2721

82. Bae SC, Lee YH (2018) Association between Vitamin D level and/or deficiency, and systemic lupus erythematosus: a metaanalysis. Cell Mol Biol 64:7-13

83. Zhao M, Duan X-H, Wu Z-Z, Gao C-C, Wang N, Zheng Z-H (2017) Severe vitamin D deficiency affects the expression of autophagy related genes in PBMCs and T-cell subsets in active systemic lupus erythematosus. Am J Clin Exp Immunol 6:43-51

84. Abdel Galil SM, El-Shafey AM, Abdul-Makoud RS, El-Boshy M (2018) Interferon alpha gene expression and serum level association with low vitamin D levels in Egyptian female patients with systemic lupus erythematosus. Lupus 27:199-209 
85. Shahin D, El-Farahaty RM, Houssen ME, Machaly SA, Sallam M, ElSaid TO, Neseem NO (2017) Serum 25-OH vitamin D level in treatment-naive systemic lupus erythematosus patients: relation to disease activity, IL-23 and IL-17. Lupus 26:917-926

86. Aranow C, Kamen DL, Dall'Era M, Massarotti EM, Mackay MC, Koumpouras F, Coca A, Chatham WW, Clowse ME, CriscioneSchreiber LG, Callahan S, Goldmuntz EA, Keyes-Elstein L, Oswald M, Gregersen PK, Diamond B (2015) Randomized, double-blind, placebo-controlled trial of the effect of vitamin D3 on the interferon signature in patients with systemic lupus erythematosus. Arthritis Rheumatol 67:1848-1857

87. Karimzadeh H, Shirzadi M, Karimifar M (2017) The effect of Vitamin D supplementation in disease activity of systemic lupus erythematosus patients with Vitamin D deficiency: a randomized clinical trial. J Res Med Sci 22:4

88. Costenbader KH, Feskanich D, Holmes M, Karlson EW, BenitoGarcia E (2008) Vitamin D intake and risks of systemic lupus erythematosus and rheumatoid arthritis in women. Ann Rheum Dis 67:530-535

89. Lima GL, Paupitz J, Aikawa NE, Takayama L, Bonfa E, Pereira RM (2016) Vitamin D supplementation in adolescents and young adults with juvenile systemic lupus erythematosus for improvement in disease activity and fatigue scores: a randomized, double-blind, placebo-controlled trial. Arthritis Care Res (Hoboken) 68:91-98

90. Zella JB, DeLuca HF (2003) Vitamin D and autoimmune diabetes. J Cell Biochem 88:216-222

91. Mathieu C, Badenhoop K (2005) Vitamin D and type 1 diabetes mellitus: state of the art. Trends Endocrinol Metab 16:261-266

92. Aljabri KS, Bokhari SA, Khan MJ (2010) Glycemic changes after vitamin $\mathrm{D}$ supplementation in patients with type 1 diabetes mellitus and vitamin D deficiency. Ann Saudi Med 30:454-458

93. Bailey R, Cooper JD, Zeitels L, Smyth DJ, Yang JH, Walker NM, Hypponen E, Dunger DB, Ramos-Lopez E, Badenhoop K, Nejentsev S, Todd JA (2007) Association of the vitamin D metabolism gene CYP27B1 with type 1 diabetes. Diabetes 56:2616-2621

94. Cooper JD, Smyth DJ, Walker NM, Stevens H, Burren OS, Wallace C, Greissl C, Ramos-Lopez E, Hypponen E, Dunger DB, Spector TD, Ouwehand WH, Wang TJ, Badenhoop K, Todd JA (2011) Inherited variation in vitamin D genes is associated with predisposition to autoimmune disease type 1 diabetes. Diabetes 60:1624-1631

95. Lopez ER, Regulla K, Pani MA, Krause M, Usadel KH, Badenhoop K (2004) CYP27B1 polymorphisms variants are associated with type 1 diabetes mellitus in Germans. J Steroid Biochem Mol Biol 89-90:155-157

96. Ramos-Lopez E, Jansen T, Ivaskevicius V, Kahles H, Klepzig C, Oldenburg J, Badenhoop K (2006) Protection from type 1 diabetes by vitamin D receptor haplotypes. Ann N Y Acad Sci 1079:327-334

97. Ramagopalan SV, Heger A, Berlanga AJ, Maugeri NJ, Lincoln MR, Burrell A, Handunnetthi L, Handel AE, Disanto G, Orton SM, Watson CT, Morahan JM, Giovannoni G, Ponting CP, Ebers GC, Knight JC (2010) A ChIP-seq defined genome-wide map of vitamin $\mathrm{D}$ receptor binding: associations with disease and evolution. Genome Res 20:1352-1360

98. Mathieu C, Waer M, Laureys J, Rutgeerts O, Bouillon R (1994) Prevention of autoimmune diabetes in NOD mice by 1,25 dihydroxyvitamin D3. Diabetologia 37:552-558

99. Li X, Liao L, Yan X, Huang G, Lin J, Lei M, Wang X, Zhou Z (2009) Protective effects of 1-alpha-hydroxyvitamin D3 on residual beta-cell function in patients with adult-onset latent autoimmune diabetes (LADA). Diabetes/Metab Res Rev 25:411-416

100. Gabbay MA, Sato MN, Finazzo C, Duarte AJ, Dib SA (2012) Effect of cholecalciferol as adjunctive therapy with insulin on protective immunologic profile and decline of residual beta-cell function in new-onset type 1 diabetes mellitus. Arch Pediatr Adolesc Med 166:601-607

101. Ataie-Jafari A, Loke SC, Rahmat AB, Larijani B, Abbasi F, Leow MK, Yassin Z (2013) A randomized placebo-controlled trial of alphacalcidol on the preservation of beta cell function in children with recent onset type 1 diabetes. Clini Nutr (Edinburgh, Scotland) 32:911-917

102. Bizzarri C, Pitocco D, Napoli N, Di Stasio E, Maggi D, Manfrini S, Suraci C, Cavallo MG, Cappa M, Ghirlanda G, Pozzilli P (2010) No protective effect of calcitriol on beta-cell function in recent-onset type 1 diabetes: the IMDIAB XIII trial. Diabetes Care 33:1962-1963

103. Walter M, Kaupper T, Adler K, Foersch J, Bonifacio E, Ziegler AG (2010) No effect of the 1alpha,25-dihydroxyvitamin D3 on beta-cell residual function and insulin requirement in adults with new-onset type 1 diabetes. Diabetes Care 33:1443-1448

104. Ananthakrishnan AN (2016) Vitamin D and inflammatory bowel disease. Gastroenterol Hepatol 12:513-515

105. Ham M, Longhi MS, Lahiff C, Cheifetz A, Robson S, Moss AC (2014) Vitamin D levels in adults with Crohn's disease are responsive to disease activity and treatment. Inflamm Bowel Dis 20:856-860

106. Jørgensen SP, Hvas CL, Agnholt J, Christensen LA, Heickendorff L, Dahlerup JF (2013) Active Crohn's disease is associated with low vitamin D levels. J Crohn's Colitis 7:e407-e413

107. Mohammad MS, Mayberry J (2013) PWE-103 vitamin $\mathrm{D}$ deficiency in crohns disease and ulcerative colitis. Gut 62:A172-A172

108. Froicu M, Weaver V, Wynn TA, McDowell MA, Welsh JE, Cantorna MT (2003) A crucial role for the vitamin D receptor in experimental inflammatory bowel diseases. Mol Endocrinol 17:2386-2392

109. Liu N, Nguyen L, Chun RF, Lagishetty V, Ren S, Wu S, Hollis B, DeLuca HF, Adams JS, Hewison M (2008) Altered endocrine and autocrine metabolism of vitamin D in a mouse model of gastrointestinal inflammation. Endocrinology 149:4799-4808

110. Lagishetty V, Misharin AV, Liu NQ, Lisse TS, Chun RF, Ouyang Y, McLachlan SM, Adams JS, Hewison M (2010) Vitamin $\mathrm{D}$ deficiency in mice impairs colonic antibacterial activity and predisposes to colitis. Endocrinology 151:2423-2432

111. Liu W, Chen Y, Golan MA, Annunziata ML, Du J, Dougherty U, Kong J, Musch M, Huang Y, Pekow J, Zheng C, Bissonnette M, Hanauer SB, Li YC (2013) Intestinal epithelial vitamin D receptor signaling inhibits experimental colitis. J Clin Investig 123:3983-3996

112. England BR, Thiele GM, Anderson DR, Mikuls TR (2018) Increased cardiovascular risk in rheumatoid arthritis: mechanisms and implications. BMJ 361:k1036-k1036

113. Tobon GJ, Youinou P, Saraux A (2010) The environment, geoepidemiology, and autoimmune disease: rheumatoid arthritis. Autoimmun Rev 9:A288-292

114. Kim K, Bang SY, Lee HS, Cho SK, Choi CB, Sung YK, Kim TH, Jun JB, Yoo DH, Kang YM, Kim SK, Suh CH, Shim SC, Lee SS, Lee J, Chung WT, Choe JY, Shin HD, Lee JY, Han BG, Nath SK, Eyre S, Bowes J, Pappas DA, Kremer JM, GonzalezGay MA, Rodriguez-Rodriguez L, Arlestig L, Okada Y, Diogo D, Liao KP, Karlson EW, Raychaudhuri S, Rantapaa-Dahlqvist S, Martin J, Klareskog L, Padyukov L, Gregersen PK, Worthington J, Greenberg JD, Plenge RM, Bae SC (2015) High-density genotyping of immune loci in Koreans and Europeans identifies eight new rheumatoid arthritis risk loci. Ann Rheum Dis 74:e13

115. Yarwood A, Huizinga TW, Worthington J (2014) The genetics of rheumatoid arthritis: risk and protection in different stages of the evolution of RA. Rheumatology 55:199-209 
116. Tracy A, Buckley CD, Raza K (2017) Pre-symptomatic autoimmunity in rheumatoid arthritis: when does the disease start? Semin Immunopathol 39:423-435

117. Lin J, Liu J, Davies ML, Chen W (2016) Serum vitamin D level and rheumatoid arthritis disease activity: review and meta-analysis. PLoS ONE 11:e0146351

118. Higgins MK, Mackie SL, Thalayasingam N, Bingham SJ, Hamilton J, Kelly CA (2013) The effect of vitamin D levels on the assessment of disease activity in rheumatoid arthritis. Clin Rheumatol 32:863-867

119. Cooles FA, Pratt AG, Lendrem DW, Ng WF, Aspray TJ, Isaacs JD (2015) Retrospective analysis of the role of serum vitamin D in early rheumatic disease. Rheumatology 54:374-375

120. Di Franco M, Barchetta I, Iannuccelli C, Gerardi MC, Frisenda S, Ceccarelli F, Valesini G, Cavallo MG (2015) Hypovitaminosis $\mathrm{D}$ in recent onset rheumatoid arthritis is predictive of reduced response to treatment and increased disease activity: a 12 month follow-up study. BMC Musculoskelet Disord 16:53

121. Furuya T, Hosoi T, Tanaka E, Nakajima A, Taniguchi A, Momohara S, Yamanaka H (2013) Prevalence of and factors associated with vitamin D deficiency in 4793 Japanese patients with rheumatoid arthritis. Clin Rheumatol 32:1081-1087

122. Haga HJ, Schmedes A, Naderi Y, Moreno AM, Peen E (2013) Severe deficiency of 25-hydroxyvitamin $\mathrm{D}(3)$ (25-OH-D(3)) is associated with high disease activity of rheumatoid arthritis. Clin Rheumatol 32:629-633

123. Emery P, Salmon M (1995) Early rheumatoid arthritis: time to aim for remission? Ann Rheum Dis 54:944-947

124. Jr GD, Holweg CTJ, Kummerfeld SK, Choy DF, Setiadi AF, Hackney JA, Haverty PM, Gilbert H, Lin WY, Diehl L, Fischer S, Song A, Musselman D, Klearman M, Gabay C, Kavanaugh A, Endres J, Fox DA, Martin F, Townsend MJ (2014) Synovial phenotypes in rheumatoid arthritis correlate with response to biologic therapeutics. Arthritis Res Ther 16:1-18

125. Hayes ME, Denton J, Freemont AJ, Mawer EB (1989) Synthesis of the active metabolite of vitamin $\mathrm{D}, 1,25(\mathrm{OH}) 2 \mathrm{D} 3$, by synovial fluid macrophages in arthritic diseases. Ann Rheum Dis 48:723-729

126. Mawer EB, Hayes ME, Still PE, Davies M, Lumb GA, Holt PJ (1991) Evidence for nonrenal synthesis of 1,25-dihydroxyvitamin D in patients with inflammatory arthritis. J Bone Miner Res 6:733-739

127. Hayes ME, Bayley D, Still P, Palit J, Denton J, Freemont AJ, Cooper RG, Mawer EB (1992) Differential metabolism of 25-hydroxyvitamin D3 by cultured synovial fluid macrophages and fibroblast-like cells from patients with arthritis. Ann Rheum Dis 51:220-226

128. Li D, Jeffery L, Jenkinson C, Harrison SR, Chun RF, Adams JS, Raza K, Hewison M (2018) Serum and synovial fluid vitamin D metabolites and rheumatoid arthritis. J Steroid Biochem Mol Biol $187: 1-8$

129. National Institute of Clinical Excellence - Clincal Knowledge $S$ (2016) Vitamin D deficiency in adults - treatment and prevention

130. National Osteoporosis S (2013) Vitamin D and bone health: a practical clinical guideline for patient management

131. Varenna M, Manara M, Cantatore FP, Del Puente A, Di Munno O, Malavolta N, Minisola G, Adami S, Sinigaglia L, Rossini M (2012) Determinants and effects of vitamin D supplementation on serum 25-hydroxy-vitamin D levels in patients with rheumatoid arthritis. Clin Exp Rheumatol 30:714-719

132. Franco AS, Freitas TQ, Bernardo WM, Pereira RMR (2017) Vitamin D supplementation and disease activity in patients with immune-mediated rheumatic diseases. Medicine 96:e7024-e7024

133. Allan GM, Cranston L, Lindblad A, McCormack J, Kolber MR, Garrison S, Korownyk C (2016) Vitamin D: a narrative review examining the evidence for ten beliefs. J Gen Intern Med 31:780-791

134. Song GG, Bae SC, Lee YH (2012) Association between vitamin $\mathrm{D}$ intake and the risk of rheumatoid arthritis: a meta-analysis. Clin Rheumatol 31:1733-1739

135. Barry EL, Rees JR, Peacock JL, Mott LA, Amos CI, Bostick RM, Figueiredo JC, Ahnen DJ, Bresalier RS, Burke CA, Baron JA (2014) Genetic variants in CYP2R1, CYP24A1, and VDR modify the efficacy of vitamin D3 supplementation for increasing serum 25-hydroxyvitamin D levels in a randomized controlled trial. J Clin Endocrinol Metab 99:E2133-2137

136. Jeffery LE, Qureshi OS, Gardner D, Hou TZ, Briggs Z, Soskic B, Baker J, Raza K, Sansom DM (2015) Vitamin D antagonises the suppressive effect of inflammatory cytokines on CTLA-4 expression and regulatory function. PLoS ONE 10:e0131539

137. Danks L, Komatsu N, Guerrini MM, Sawa S, Armaka M, Kollias G, Nakashima T, Takayanagi H (2016) RANKL expressed on synovial fibroblasts is primarily responsible for bone erosions during joint inflammation. Ann Rheum Dis 75:1187-1195

138. Rodriguez-Fernandez JL (2013) Antigen presentation by dendritic cells in rheumatoid arthritis. Curr Top Med Chem 13:712-719

139. Klareskog L (1991) Antigen presentation in joints in the pathogenesis of arthritis. Br J Rheumatol 30(Suppl 1):53-57

140. Nistala K, Adams S, Cambrook H, Ursu S, Olivito B, de Jager W, Evans JG, Cimaz R, Bajaj-Elliott M, Wedderburn LR (2010) Th17 plasticity in human autoimmune arthritis is driven by the inflammatory environment. Proc Natl Acad Sci USA 107:14751-14756

141. van Hamburg JP, Asmawidjaja PS, Davelaar N, Mus AM, Colin EM, Hazes JM, Dolhain RJ, Lubberts E (2011) Th17 cells, but not Th1 cells, from patients with early rheumatoid arthritis are potent inducers of matrix metalloproteinases and proinflammatory cytokines upon synovial fibroblast interaction, including autocrine interleukin-17A production. Arthritis Rheum 63:73-83

142. Stoop JN, Harry RA, von Delwig A, Isaacs JD, Robinson JH, Hilkens CMU (2010) Therapeutic effect of tolerogenic dendritic cells in established collagen-induced arthritis is associated with a reduction in Th17 responses. Arthritis Rheum 62:3656-3665

143. Bscheider M, Butcher EC (2016) Vitamin D immunoregulation through dendritic cells. Immunology 148:227-236

144. Anderson AE, Swan DJ, Wong OY, Buck M, Eltherington O, Harry RA, Patterson AM, Pratt AG, Reynolds G, Doran JP, Kirby JA, Isaacs JD, Hilkens CM (2017) Tolerogenic dendritic cells generated with dexamethasone and vitamin D3 regulate rheumatoid arthritis CD4(+) T cells partly via transforming growth factor-beta1. Clin Exp Immunol 187:113-123

145. Ponchel F, Goëb V, Parmar R, El-Sherbiny Y, Boissinot M, El Jawhari J, Burska A, Vital EM, Harrison S, Conaghan PG, Hensor E, Emery P (2014) An immunological biomarker to predict MTX response in early RA. Ann Rheum Dis 73:2047-2053

146. Langdon K, Haleagrahara N (2018) Regulatory T-cell dynamics with abatacept treatment in rheumatoid arthritis. Int Rev Immunol 37:206-214

147. Li N, Wei W, Yin F, Chen M, Ma TR, Wu Q, Zhou JR, Zheng S-G, Han J (2015) The abnormal expression of CCR47 and CCR47 on Tregs in rheumatoid arthritis. Int J Clin Exp Med $8: 15043-15053$

148. Wang T, Sun X, Zhao J, Zhang J, Zhu H, Li C, Gao N, Jia Y, Xu D, Huang F-P, Li N, Lu L, Li Z-G (2015) Regulatory T cells in rheumatoid arthritis showed increased plasticity toward Th17 but retained suppressive function in peripheral blood. Ann Rheum Dis 74:1293-1301

149. Cooles FAH, Isaacs JD, Anderson AE (2013) Treg cells in rheumatoid arthritis: an update. Curr Rheumatol Rep 15:352 
150. Moradi B, Schnatzer P, Hagmann S, Rosshirt N, Gotterbarm T, Kretzer JP, Thomsen M, Lorenz H-M, Zeifang F, Tretter T (2014) $\mathrm{CD} 4{ }^{+} \mathrm{CD} 25+/$ high $\mathrm{CD} 127$ low/- regulatory T cells are enriched in rheumatoid arthritis and osteoarthritis joints-analysis of frequency and phenotype in synovial membrane, synovial fluid and peripheral blood. Arthritis Res Ther 16:R97-R97

151. Baeke F, Korf H, Overbergh L, Verstuyf A, Thorrez L, Van Lommel L, Waer M, Schuit F, Gysemans C, Mathieu C (2011) The vitamin $\mathrm{D}$ analog, TX527, promotes a human CD4+CD25 high $\mathrm{CD} 127$ low regulatory $\mathrm{T}$ cell profile and induces a migratory signature specific for homing to sites of inflammation. J Immunol 186:132-142

152. Van Belle TL, Vanherwegen A-S, Feyaerts D, De Clercq P, Verstuyf A, Korf H, Gysemans C, Mathieu C (2014) 1,25-Dihydroxyvitamin D3 and Its Analog TX527 Promote a Stable Regulatory T Cell Phenotype in T Cells from Type 1 Diabetes Patients. PLoS ONE 9:e109194-e109194

153. Jeffery LE, Henley P, Marium N, Filer A, Sansom DM, Hewison M, Raza K (2018) Decreased sensitivity to 1,25-dihydroxyvitamin D3 in T cells from the rheumatoid joint. J Autoimmun 88:50-60

154. Gardner DH, Jeffery LE, Soskic B, Briggs Z, Hou TZ, Raza K, Sansom DM (2015) 1,25(OH)2D3 promotes the efficacy of CD28 costimulation blockade by abatacept. J Immunol 195:2657-2665

155. Gu X, Gu B, Lv X, Yu Z, Wang R, Zhou X, Qiao W, Mao Z, Zuo G, Li Q, Miao D, Jin J (2016) 1, 25-dihydroxy-vitamin D3 with tumor necrosis factor-alpha protects against rheumatoid arthritis by promoting p53 acetylation-mediated apoptosis via Sirt1 in synoviocytes. Cell Death Dis 7:e2423

156. van Hamburg JP, Asmawidjaja PS, Davelaar N, Mus AMC, Cornelissen F, van Leeuwen JPTM, Hazes JMW, Dolhain RJEM,
Bakx PAGM, Colin EM, Lubberts E (2012) TNF blockade requires $1,25(\mathrm{OH}) 2 \mathrm{D} 3$ to control human Th17-mediated synovial inflammation. Ann Rheum Dis 71:606-612

157. Feng X, Lv C, Wang F, Gan K, Zhang M, Tan W (2013) Modulatory effect of 1,25-dihydroxyvitamin D 3 on IL1 $\beta$-induced RANKL, OPG, TNF $\alpha$, and IL-6 expression in human rheumatoid synoviocyte MH7A. Clin Dev Immunol 2013:160123

158. Tetlow LC, Woolley DE (1999) The effects of 1 alpha,25-dihydroxyvitamin $\mathrm{D}(3)$ on matrix metalloproteinase and prostaglan$\operatorname{din} E(2)$ production by cells of the rheumatoid lesion. Arthritis Res 1:63

159. Martineau AR, Jolliffe DA, Hooper RL, Greenberg L, Aloia JF, Bergman P, Dubnov-Raz G, Esposito S, Ganmaa D, Ginde AA, Goodall EC, Grant CC, Griffiths CJ, Janssens W, Laaksi I, Manaseki-Holland S, Mauger D, Murdoch DR, Neale R, Rees JR, Simpson S Jr, Stelmach I, Kumar GT, Urashima M, Camargo CA Jr (2017) Vitamin D supplementation to prevent acute respiratory tract infections: systematic review and meta-analysis of individual participant data. BMJ 356:i6583

160. Sanders KM, Stuart AL, Williamson EJ, Simpson JA, Kotowicz MA, Young D, Nicholson GC (2010) Annual high-dose oral vitamin $\mathrm{D}$ and falls and fractures in older women: a randomized controlled trial. JAMA 303:1815-1822

Publisher's Note Springer Nature remains neutral with regard to jurisdictional claims in published maps and institutional affiliations. 